S 6 Z

\begin{tabular}{|l|l|}
\hline $\begin{array}{l}\text { 2. To: (Recelving Organization) } \\
\text { CHG Characterization Engineering }\end{array}$ & $\begin{array}{l}\text { 3. From: (Originating Organization) } \\
\text { CHG Characterization Engineering }\end{array}$ \\
\hline $\begin{array}{l}\text { 5. Proj./Prog./Dept./Div.: } \\
\text { Characterization Engineering }\end{array}$ & $\begin{array}{l}\text { 6. Deslon Authorlty/Design AgentCog. Engr.: } \\
\text { GP Janicek/RG Brown }\end{array}$ \\
\hline
\end{tabular}

\section{Originator Remarks:}

RELEASE:

4. Related EDT No.:

N/A

7. Purchase Order No.:

$N / A$

9. Equlp./Component No.:

$\mathrm{N} / \mathrm{A}$

10. Syatem/Bldg./Facility:

200G

12. Major Asam. Dwg. No.:

$\mathrm{N} / \mathrm{A}$

13. Permil/Permilt Appllcation No.:

N/A

14. Requlred Reepones Date:

N/A

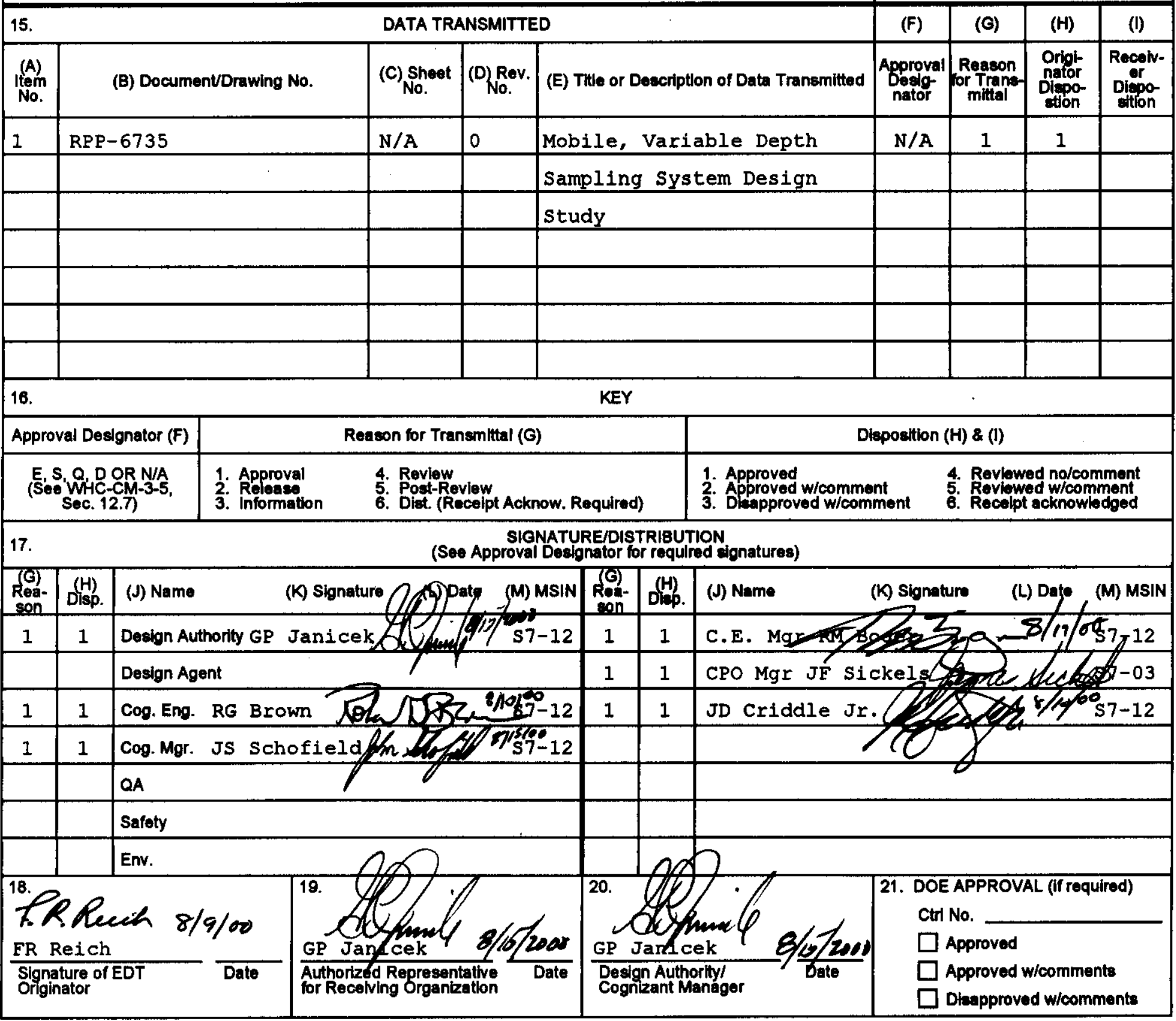




\title{
MOBILE, VARIABLE DEPTH SAMPLING SYSTEM DESIGN STUDY
}

\author{
R. M. BOGER \\ CH2M HILL Hanford Group, Inc., Richland, WA 99352 \\ U.S. Department of Energy Contract DE-AC06-96RL13200
}

EDT/ECN: 629377

Org Code: 74900

B\&R Code: EW3130000
UC: 2000

Charge Code: 102254/E100

Total Pages: 48

Key Words: Sampling system, Tank waste, At-tank analysis, Pre-Conceptual Design, RCRA Sampler, Mobile, variable depth sampler, double-shell, LAW, HLW.

Abstract: A design study is presented for a mobile, variable depth sampling system (MVDSS) that will support the treatment and immobilization of Hanford LAW and HLW. The sampler can be deployed in a 4-inch tank riser and has a design that is based on requirements identified in the Level 2 Specification (latest revision). The waste feed sequence for the MVDSS is based on Phase I, Case 3S6 waste feed sequence. Technical information is also presented that supports the design study.

TRADEMARK DISCLAIMER. Reference herein to any specific commercial product, process, or service by trade name, trademark, manufacturer, or otherwise, does not necessarily constitute or imply its endorsement, recommendation, or favoring by the United States Government or any agency thereof or its contractors or subcontractors.

Printed in the United States of America. To obtain copies of this document, contact: Document Control Services, P.O. Box 950, Mailstop H6-08, Richland WA 99352, Phone (509) 372-2420; Fax (509) 376-4989.
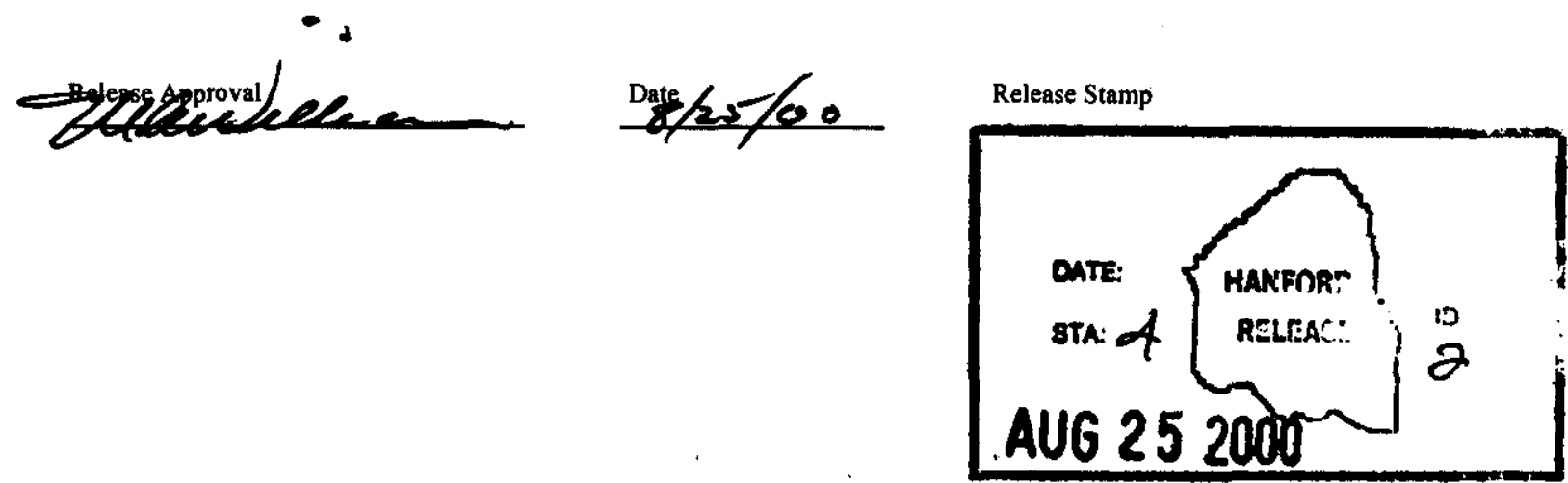


\title{
MOBILE, VARIABLE DEPTH SAMPLING SYSTEM DESIGN STUDY
}

\author{
HNF 6735 Revision 0
}

\author{
Prepared For \\ River Protection Project \\ CH2M HILL Hanford Group, Inc. \\ Characterization Engineering \\ Richland, WA
}

By F. R. Reich

COGEMA Engineering Corporation

Richland, Washington

August 2000 


\section{TABLE OF CONTENTS}

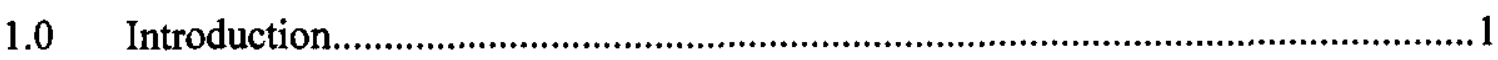

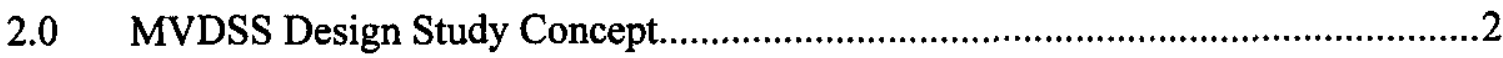

$2.1 \quad$ Sample Bottle Filling System .................................................................... 3

2.2 Segmented Mast........................................................................................... 3

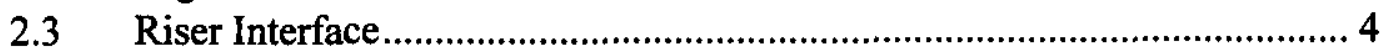

2.4 Sampling System Platform ......................................................................... 4

2.4.1 Variable Depth Hose Reel .............................................................5

2.4.2 Control System ..................................................................................

2.4.3 Fluidic Pumping System - Charge Vessel and RFD..........................6

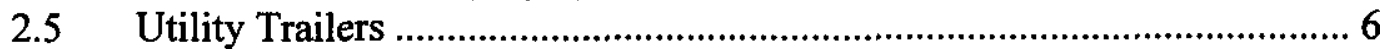

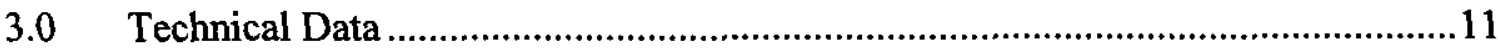

3.1 Mast Force Calculations ....................................................................... 14

3.1.1 Mast Horizontal Force ...................................................................14

3.1.2 Minimum Allowable Bend Radius ................................................15

3.1.3 Segmented Mast Fatigue Strength .................................................15

3.2 Tank Riser and Dome Load Limits ....................................................... 17

3.3 Tank Waste Physical, Chemical, and Radiological Properties.................. 18

3.4 Dome Space (Physical and Chemical) Environment ................................ 20

3.5 Tank Farm (Above Grade) Environment.................................................. 20

3.6 Fluidic Pump Design Envelope Parameters for 4.0-Inch Riser Deployment

$3.7 \quad$ Tank Riser Size Availability................................................................. 24

3.8 Hanford Steel Pig Sample Carrier ........................................................... 28

$3.9 \quad 500-\mathrm{mL}$ Sample Bottle............................................................................. 31

Human Engineering .......................................................................................... 33

3.10 Utility Support for Sampling System ..................................................... 33

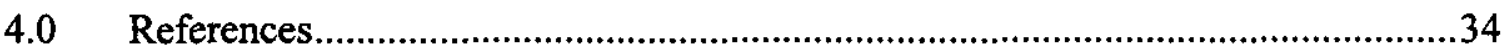

\section{FIGURES}

Figure 1 Mobile, Variable Depth Sampling System with an At-Tank Analysis System deployed in a Double-Shell Tank

Figure 2 Typical MVDSS mast segment constructed from $31 / 2$-inch outside diameter drill rod that has a slot for access to tank waste............................................................ 8

Figure 3 Installation (and removal) of the in-tank mast using an" A-Frame" hoist. ...........9

Figure 4 Side view of the MVDSS showing the details of its modules. ...........................10

Figure 5 Low-Activity Waste Feed Staging Sequence for Phase 1, Case 3S6 (HNF-SD-

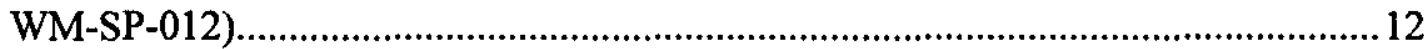


Figure 6 High-Level Waste Feed Staging Sequence for Phase 1, Case 3S6 (HNF-SDWM-SP-012, Rev. 2).

Figure 8 Cross-section of mast and charge vessel for 4-inch riser deployment showing integrated cable and piping.

Figure 9 Hanford Steel Pig sample carrier currently used for shipping waste sample bottles, including the $500-\mathrm{mL}$ sample bottle.

Figure 10 Hanford Steel Pig Sample Carrier showing potential dimensions that would increase radiation shielding.

Figure $11500-\mathrm{mL}$ brown-glass, wide-mouth sample bottle (Owens-Brockway bottle, C7651 (drawing FR-16990-A-2) ...........................................................................

Figure 12 Von Mises stress plot for 10-psi internal pressure for the $500-\mathrm{mL}$ wide-mouth sample bottle.

\section{TABLES}

Table 1 Waste feed tank (Case 3S6) and corresponding allowable dome loading .......18

Table 2 Fluidic pump design parameters

Table 3 Available risers for Phase 1, Case 3S6 LAW and HLW tanks for MVDSS deployment

\section{APPENDICES}

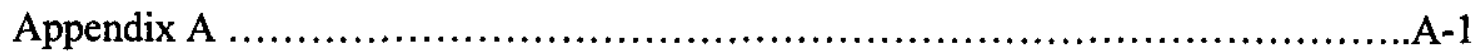

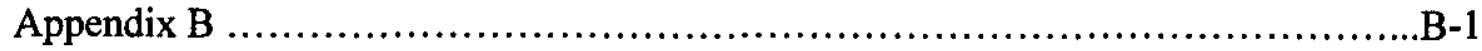

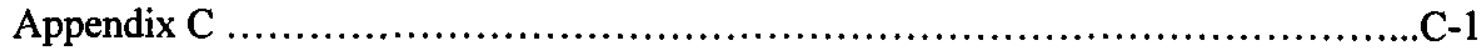




\section{ACRONYMS AND ABBREVIATIONS}

ALARA - As low as reasonably achievable.

ATAS - At-tank analysis system

AEAT - AEA Technology Engineering Services, Inc.

Barg - Bar, gauge (one bar equals 1 atmosphere)

cp - Centipoise $\left(10^{-2}\right.$ poise $)$

DST - Double-shell tank

HLAN - Hanford Local Area Network

HLW - High level waste

ID - Inside diameter

$\mathrm{KVA}-10^{3}$ volt-ampere

LAW - Low activity waste

LLCE - Long length contaminated equipment

MVDSS - Mobile, variable depth sampling system

OD - Outside diameter

PWSS - Process waste sample subsystem

RCRA - Resource Conservation Recovery Act

RFD - Reverse flow diverter.

RPP - River Protection Project

TBD - To be determined

WFD - Waste feed delivery

wt $\%$ - Percent by weight 


\section{Acknowledgement}

This document was completed by the COGEMA technical team that developed the preconceptual design for the mobile, variable depth sampling system. The contributions from individual team members, J.D. Criddle, B.L. Coverdel, P.J Fuller, T.M. Galioto, R.L. Miller, and G.W. Wilson are acknowledged and appreciated. 


\subsection{Introduction}

The River Protection Program (RPP) has the responsibility to treat and immobilize the highly radioactive Hanford Site tank waste (Tanks Waste Remediation System Privatization Contract DE-AC06-96RL13308, Mod. No. A006, 1998, U.S. Department of Energy, Richland, Washington). Prior to transfer to the treatment and immobilization plant, waste samples of waste batches will be taken and sample material will be analyzed in the $222 \mathrm{~S}$ laboratory to verify the waste batches meet the low activity waste (LAW) and high level waste (HLW) envelopes (waste envelopes A, B, C, and D), archived, and provided to the LAW/LAW plant operator, as required by the vitrification project (BNFL-5193-ID-19, Rev. 4e, 2000 and BNFL5193-ID-20, Rev. 4f, 2000).

A design study has been completed for a mobile, variable depth sampling system (MVDSS) that will provide this sampling function. This sampling system will be part of the DST Process Waste Sampling Subsystem (PWSS) that provides sampling support for Waste Feed Delivery (WFD) (Rassmussen, 2000a). The PWSS consists of structures and components that obtain samples of DST contents, perform any field observations or analyses of the samples, and deliver samples to laboratories for subsequent detailed analysis. The overall definitions for performance requirements and the requisite codes and standards to be applied to this MVDSS are identified in the Level 2 Specification (Reich, 1999) that flow down from, Double-Shell Tank Process Waste Sampling Subsystem Specification (Rassmussen, 2000b).

This document describes a concept for an MVDSS and also contains technical information that was identified during the completion of the design study. Portions of this concept borrow on equipment already in use for core sampling of Hanford's tank wastes. This document is not a requirements document. The design study was based on the current Level 2 Specification (Reich, 1999). The technical information in this document will be used to revise the current Level 2 Specification. 


\subsection{MVDSS Design Study Concept}

The MVDSS is based on a modular concept that includes both in-tank and above ground hardware modules as indicated in Figure 1. The main include:

- $\quad$ Segmented mast

- $\quad$ Fluidic pumping system charge vessel and reverse flow diverter (RFD)

- $\quad$ Tank riser interface

- $\quad$ Sampling system platform

- $\quad$ Variable depth sampling system

- Sample bottle filling system

- Utility trailer(s)

The MVDSS will also provide an interface for an at-tank analysis system (ATAS). The ATAS was not part of this design study and will be addressed in future conceptual design activities.

The above-ground modules are moveable and will be capable of being used with any of the LAW and HLW feed tanks with changes in interface hardware that will accommodate variations in tank risers (diameter and flange elevations). The in-tank mast, charge vessel and RFD, riser interface, and support platform can remain installed on a specific tank until all sampling needs are met. The in-tank components will then be disposed of as contaminated hardware when they are removed from a tank. However, the riser interface and its supporting platform may be re-used on other tanks.

The specifications and criteria for the MVDSS are contained in the Level 2 Specification (Reich, 1999). This includes the following:

- Provide LAW and HLW waste samples from Phase 1 DST feed staging tanks that are chemically and physically representative of the waste contents in a feed batch as required for DST waste processing and final disposal

- Allow relatively large volumes of sample material to be obtained with minimal impact from weather conditions currently affecting the baseline, grab sampling method, and without adverse impacts from other in-tank operations, including mixer pumps, decanting operations, etc.

- Fill 500-mL sample bottles capable of meeting RCRA criteria for volatile and semivolatile organics and package them for shipping with the Hanford Site Pig transportation (Steel Pig, Shipping Pig, and N55 over-pack) system.

- While the DST mixer pumps are operating, provide representative samples from any elevation in the waste, with a sample elevation positioning accuracy of \pm 1.0 -inch.

- Provide sampling at a rate such that 10 liters of samples may be obtained within an 8-hour period, consisting of at least two 500 -mL samples obtained from at least 8 different tank waste elevations.

- Include spray wash, waste flushing hardware to decontaminate waste contacting surfaces and waste disposal via a drain system back into the waste tank. 
- Provide a design, with construction and deployment methods, that is compatible with the waste, the tank dome airspace, tank farm environments and meets all tank farm requirements including dimensional limits, riser and dome loading limits and environmental, safety, and regulatory criteria.

- Provide radiation shielding and contamination control as required by tank farms system deployed in LAW and HLW tanks.

- Provide a waste loop and utilities interface for the operation of an at-tank analysis system (ATAS).

\subsection{Sample Bottle Filling System}

The sample bottle filling system and the fluidic pumping system, including the charge vessel and RFD and its Jet-Pump air pressure/vacuum driver system will be provided by AEAT. These modules will be installed in the MVDSS and will require coordination of interfaces to assure that the system requirements in the Level 2 Specification can be met.

\subsection{Segmented Mast}

The segmented mast is designed to be deployed in a 4-inch tank riser which will allow sampling for all of the LAW and HLW waste batches in the feed tanks defined by the Phase I, Case 3S6 waste feed sequence (see Figures 5 and 6) (Kirkbride, 2000). This segmented mast is similar in structure to the drill string that the current core truck system deploys.

A proposed mast concept is indicated in Figure 2. The segmented mast is made up of 5-foot long sections of $3 \frac{1}{2}$ inch outside diameter drill rod. These sections will be attached to each other with 4 pitch square thread and then tightened (torque level is TBD). The fluidic pumping system charge vessel and RFD will ride up and down inside the segmented mast, which is open and clear, with "clothes-line" cable concept. The lowest mast section will have a pulley unit to guide the "pay-out" cable that is connected to the bottom of the charge vessel/fluidic pump and is used to pull these components downward. The flexible hoses connected to the top of the charge vessel (waste and air/vacuum hoses) will pull the charge vessel upward (hose bundle may include a cable member). The cable and the hoses will act like a "clothes-line" pulley system and provide sampling (positive positioning) from any tank waste batch elevation.

The mast sections that are below the maximum anticipated waste level will have a slot in the side, as indicated in Figure 2, so the RFD sampling inlet has direct access to the tank waste. The mast segments will be fabricated and assembled so that their slots are vertically aligned when installed. A rail or pins, on the inside of the mast, will prevent the rotation of the RFD and charge vessel so that it is aligned with the slit for access to tank waste.

The weight of the mast will be supported by the sampling system platform through the riser interface. The upper, last mast segment will be a transition piece that connects the mast to the riser interface. The length of this upper mast segment can be modified so that the bottom of the 
mast is located just above the bottom of a waste tank. The riser interface will provide lateral and vertical support for the mast. The mast will experience lateral forces from the mixer pumps that will also be installed in the feed tanks (see Appendix A).

The mast will be deployed using a hoist that will lower the mast into the tank as each section is added (see Figure 3). A footclamp assembly will support the deployed sections while additional sections are attached. The transition piece and the fluidic pump will be installed to complete the mast installation process. The hoist system will also be used to recover the contaminated mast segments, charge vessel, and RFD in the manner currently used with the core truck sampling system drill string. As an option, the long length contaminated equipment (LLCE) system could also be used for recovery and disposal without the need to dismantle the mast into short segments.

\subsection{Riser Interface}

A riser interface module (see Figure 3) is the interface between the segmented mast and the variable depth sampling module and provides horizontal and lateral support for the mast. The tank riser interface contains a large valve or a plug, a drill rod spray washer with a pipe wiper that provides a seal between the mast and the drill rod washer, a foot-clamp assembly, and adapters to interface with the tank riser, as indicated in Figure 4. The valve will allow the MVDSS, with the exception of the sampling system platform and riser interface to be removed from the tank while maintaining tank containment. A drill rod washer provides the means to wash the mast and the charge vessel and RFD components as they are removed for disposal. The foot-clamp is used to support the mast or mast sections during deployment, sampling operations, and retrieval

Interface hardware, including riser spool piece, will be custom designed for each waste tank riser and will accommodate riser size and flange elevation variations between the waste tanks as some of the risers are below grade. This riser interface will allow the MVDSS to be deployed in different sized risers ( the minimum riser size is 4 inches)..

\subsection{Sampling System Platform}

As indicated in Figure 1, the sampling system platform provides the support base for the following modules:

- Sample bottle filling system

- Variable depth hose reel system

- At-tank analysis system

- Control system

The sampling system platform is positioned over a tank riser and can be supported by adjustable height legs setting on dunnage that can be installed at grade level around the riser. 
This will enable the platform to be leveled and adjusted for variations in riser flange elevations. The sampling platform interfaces with the mast through the riser interface module. An operator "cat-walk" or man-lift may be provided on the platform. The structural strength of the sampling platform supports the total weight of the modules located on it.

\subsubsection{Variable Depth Hose Reel}

The variable depth hose reel module interfaces with the waste tank through the tank riser interface module, as shown in Figure 4. The variable depth hose reel module contains two reel systems. This module provides waste, utility, and structural interfaces for the at-tank analysis system and the sample bottle filling system. The vertical drum reel contains a flexible waste sampling hose and flexible fluidic pump drive hose (air and vacuum to drive the charge vessel). It provides a hose "take-up" function that raises and lowers the charge vessel and RFD inside the mast. A second reel provides a "pay-out" function for the cable that is attached to the bottom of the charge vessel and wrapped around on the lowest mast segment. The two reels are synchronized so that there is minimal slack in the flexible hoses and cable.

The flexible waste hose that is attached to the charge vessel is used to position the RFD to sample waste at any elevation within the tank. The hose reel is oriented vertically to allow it to self-drain. Waste loop piping is included in the variable depth sampling system so that waste can be pumped through the system without porting it through the sample bottle filling system or the at-tank analysis system. The variable depth hose reel enclosure also includes piping for drain waste and flush water that is used to remove residual waste from the sample bottle filling system and ATAS, back into the waste tank (a single return/drain pipe may be sufficient). Valve manifolds in this module control the porting of waste, flush water, and residual waste.

The variable depth hose reel housing is shielded to limit the dose that operators will acquire when operating the system. The AEAT furnished jet pump drive and its valve control manifold are also located in this housing.

\subsubsection{Control System}

The MVDSS is operated from a control panel mounted on the sampling platform. The control system is mounted in an environmentally controlled enclosure. All operational functions of the MVDSS, with the exception of sample bottle handling, will be controlled by the locally mounted control system. The operator interfaces with the sampling system through the discrete control devices that are mounted on the control panel. A ruggedized operator interface panel may be required. The MVDSS operations controlled from the local control system include the following:

- Fluidic pumping system monitoring and control.

- At-tank sensor system data readout 
- All interlocks, actuators, and status indicators required to support safe operation and waste containment.

- Data acquisition and interfacing. Data will be stored locally on a temporary basis. Data ports mounted in or on the control enclosure will be provided for electronic data transfer and hardcopy generation. A Hanford Local Area Network (HLAN) connection will also be provided.

- Electrical power monitoring.

- Flush water control and monitoring.

Control System power conditioning equipment for buffering and fusing the electrical power will be included in the control panel.

\subsubsection{Fluidic Pumping System - Charge Vessel and RFD}

The waste sampling uses the AEAT pumping system that is based on their fluidic RFD pumping technology. The design of the fluidic pumping system will be completed by AEAT and is not part of this design study. The mast provides the "rail" on which the fluidic pump charge vessel and RFD components will ride up and down inside the tank. The outlet from the fluidic pump will be connected to flexible hose on the variable hose reel system. The charge vessel pumping drive is from a AEAT provided jet-pump system. As indicated in Figure 4, the jet-pump system is housed in the variable depth sampling system enclosure.

\subsection{Utility Trailers}

The electrical power source for the utility support module is provided by a motor-driven electrical generator: 110 volt, $60 \mathrm{~Hz}$ power for light duty power needs and potentially 480 volt, $60 \mathrm{~Hz}$ for heavy-duty power needs. The utility trailers provide a portable platform for the power distribution panel, for the air compressor (size is TBD) and accumulator, and the $150 \mathrm{gal}$ water supply tank and a high pressure pump. The utility trailers may also provide storage for tools and mast sections. The utilities that are required to operate the MVDSS include electrical power, compressed air, and flush water.

An environmental enclosure protects the electrical systems from adverse tank farm environmental conditions. A separate electrical connection is provided to enable the MVDSS to use tank farm electrical power when the system is in extended standby (maintain temperature control and etc.). Sensors and transducers provide status for the utilities during the operation of the sampling and at-tank analysis systems that is input to the data acquisition system.

Water for flushing and/or decontamination is provided from a temperature-controlled water reservoir mounted on a separate trailer. The water level in the reservoir and the rate of flow from the reservoir are some of the data that will be input to the data acquisition system. 


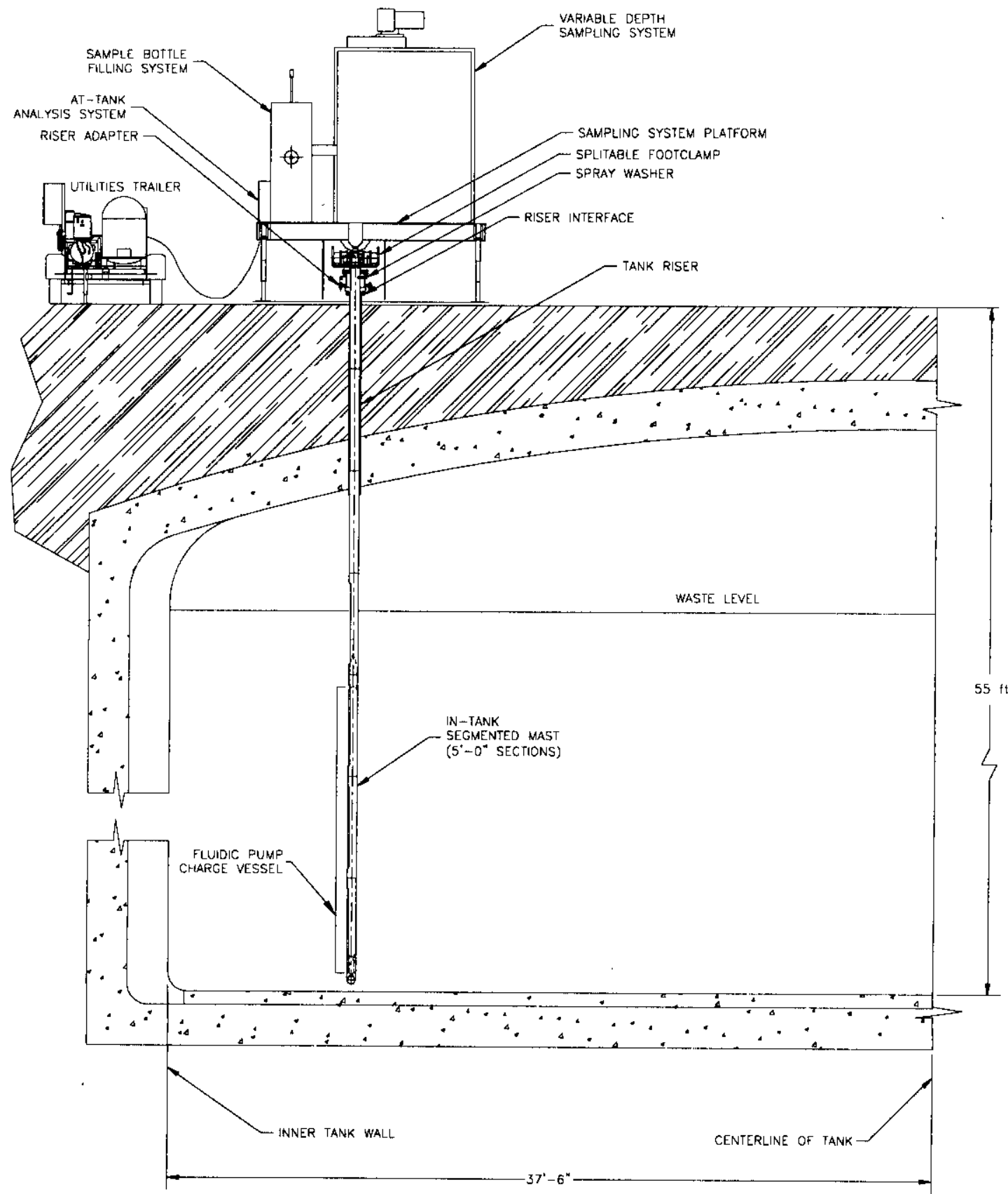

Figure 1 Mobile, Variable Depth Sampling System with an At-Tank Analysis System deployed in a Double-Shell Tank 
RPP-6735, REV. 0
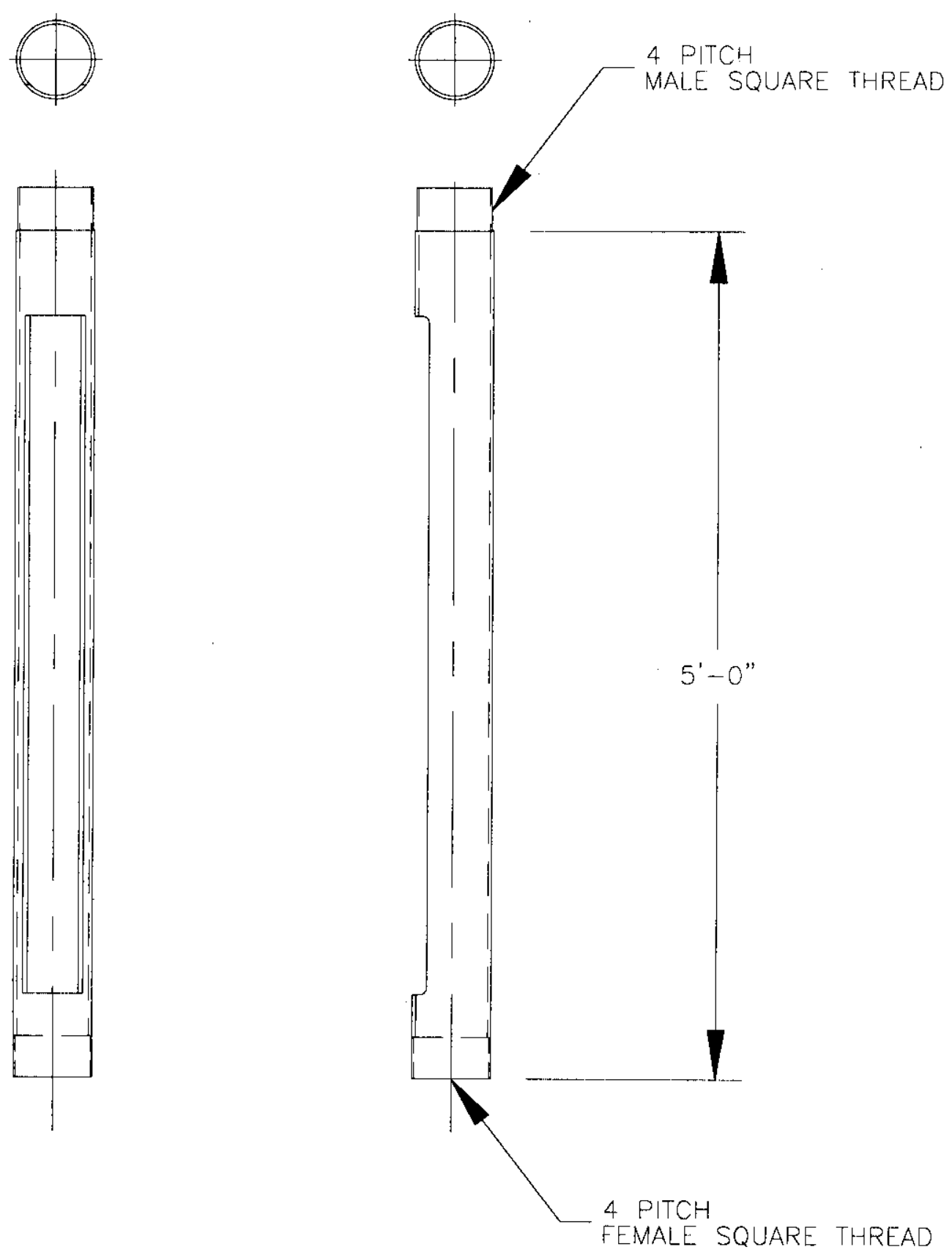

$31 / 2$ OD DRILL ROD

Figure 2 Typical MVDSS mast segment constructed from $3 \frac{1}{2}$-inch outside diameter drill rod that has a slot for access to tank waste. 
RPP-6735, REV. 0

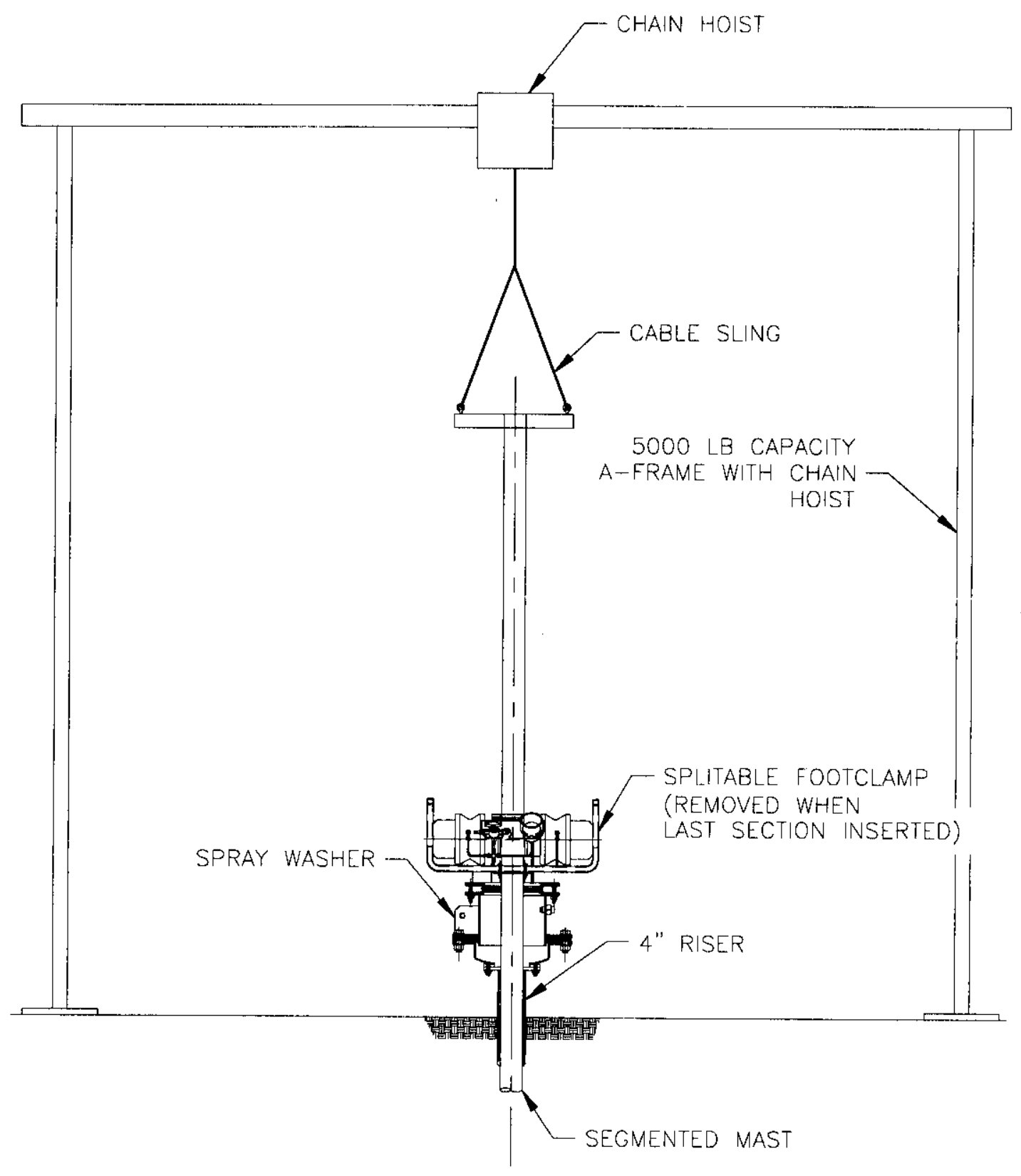

Figure 3 Installation (and removal) of the in-tank mast using an" A-Frame" hoist. 


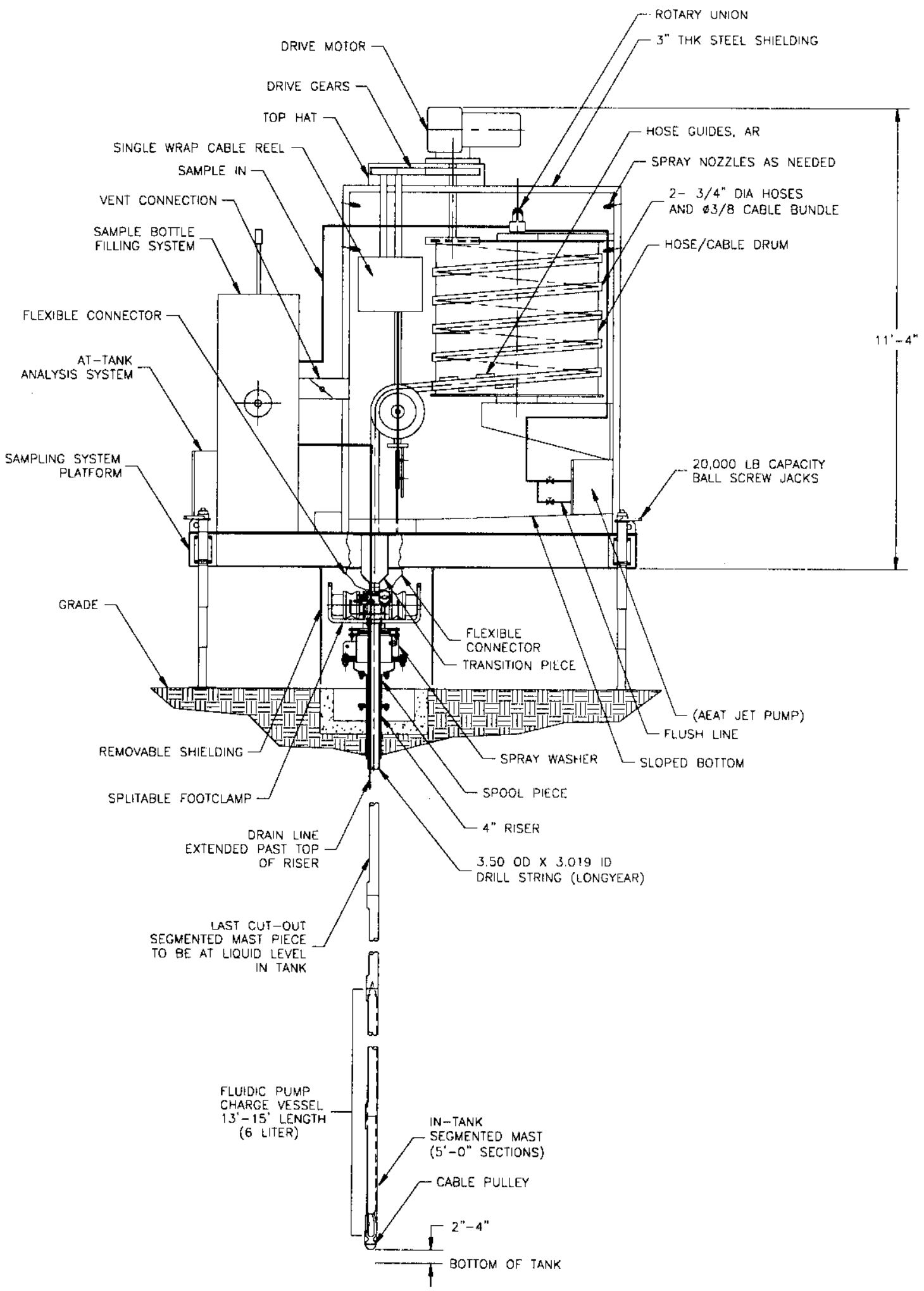

Figure 4 Side view of the MVDSS showing the details of its modules. 


\subsection{Technical Data}

The MVDSS concept, shown in Section 2.0, is based on the Level 2 Specification (Reich, 1999) and technical information included in this section. The technical information in this section does not constitute design requirements at this juncture. However, it will be used, as appropriate, to revise and update the Level 2 Specification.

The LAW and HLW waste batch feed staging sequences that this MVDSS will provide waste sampling is the Phase 1, Case 3S6 shown in Figures 5 and 6 (Kirkbride, 2000). The sampling system would be installed in the staging tanks where the waste is staged just prior to transfer to the LAW/HLW plant. 


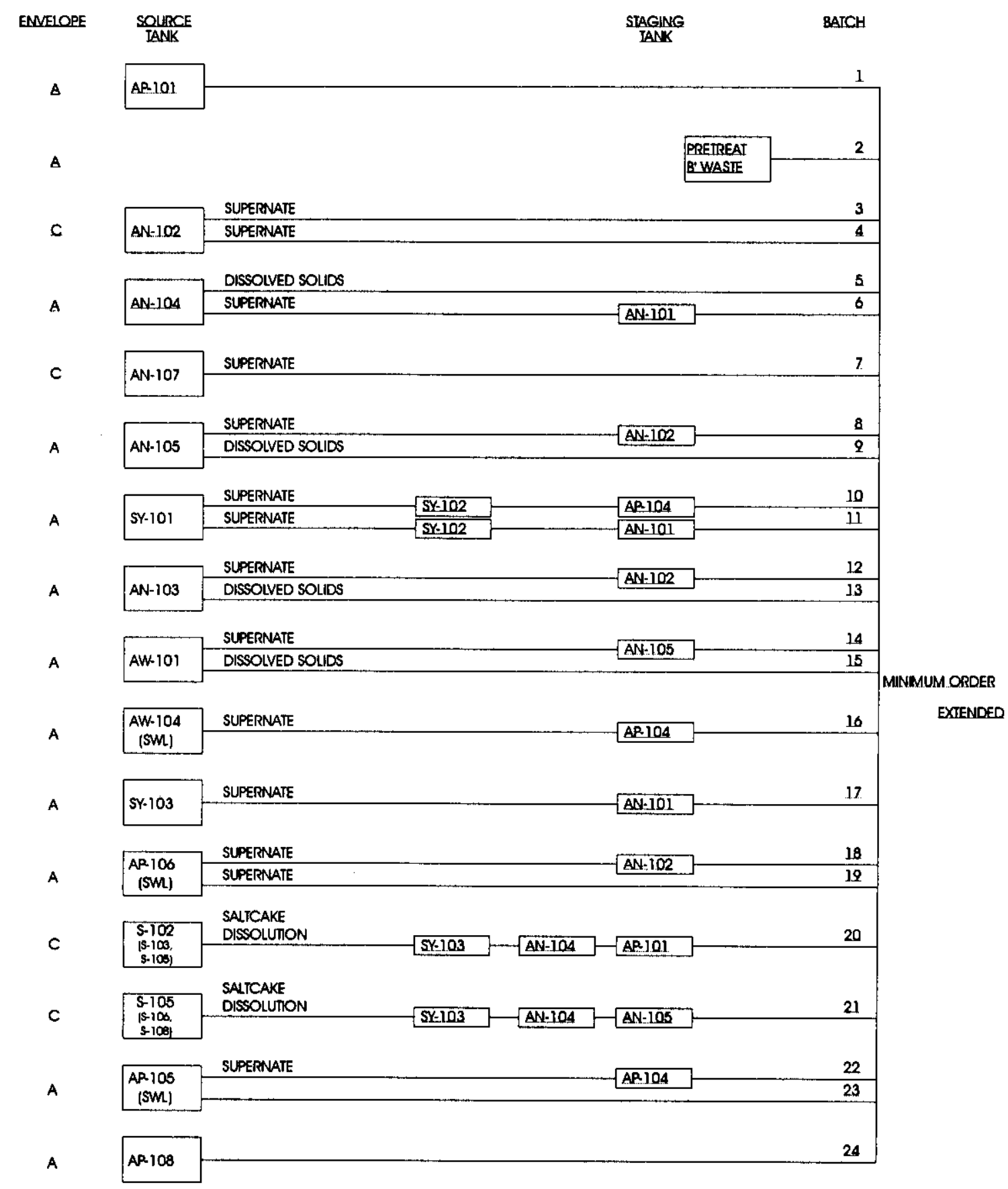

Figure 5 Low-Activity Waste Feed Staging Sequence for Phase 1, Case 3S6 (HNF-SD-WMSP-012). 
RPP-6735, REV. 0

HIGH-LEVEL WASTE FEED STAGING SEQUENCE-CASE 3S6 PHASE 1

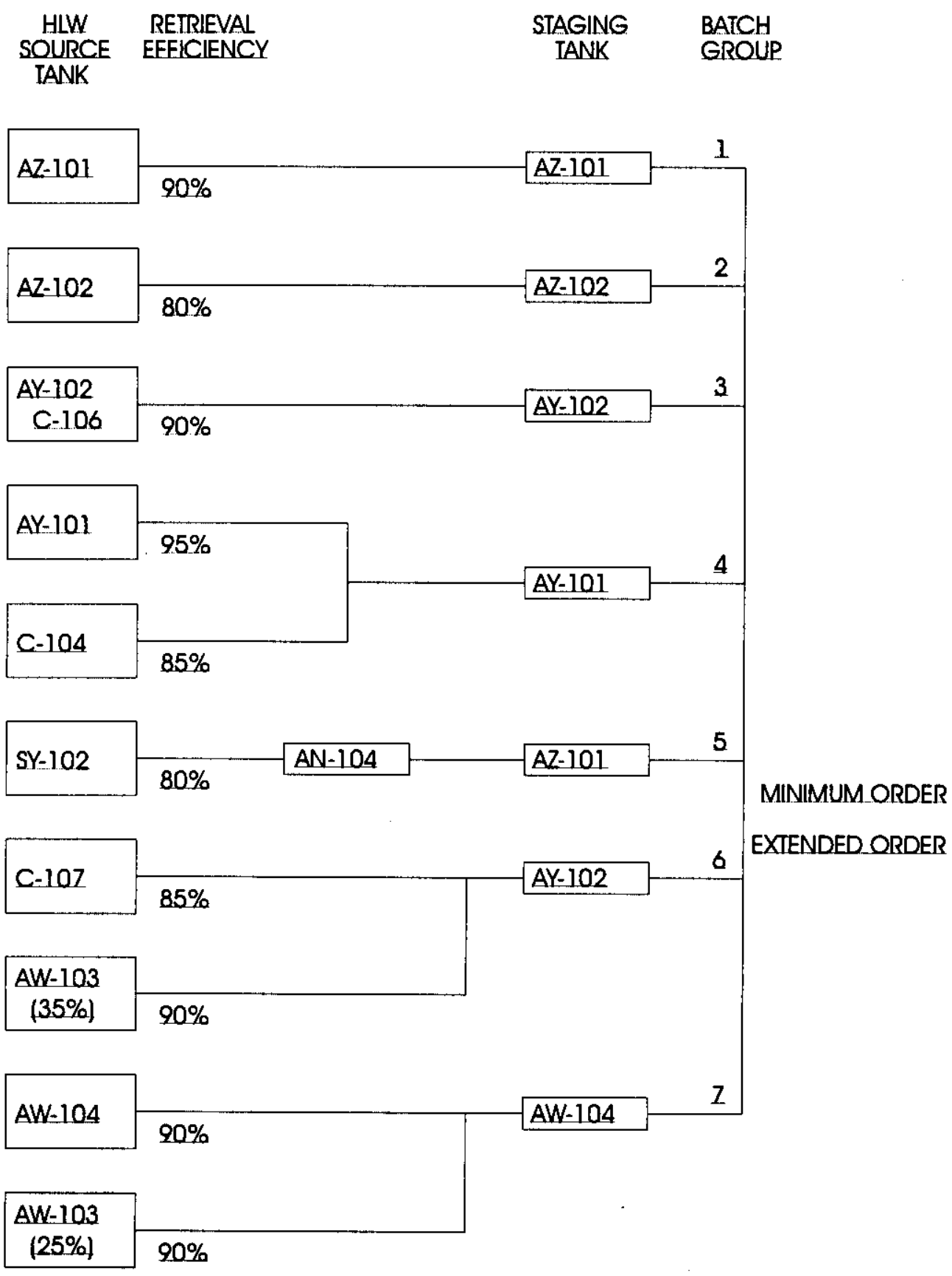

Figure 6 High-Level Waste Feed Staging Sequence for Phase 1, Case 3S6 (HNF-SD-WM-SP012, Rev. 2). 


\subsection{Mast Force Calculations}

Table A-1, in Appendix A, shows the mixer pumps that are planned to be deployed for the Case 3S6 Phase 1 LAW and HLW DST feed tanks. The effluent from these mixer pumps will impart horizontal forces to a sampling system deployed in these waste tanks. The calculated data, shown below, are based on a segmented mast constructed from $3 \frac{1}{2}$-in outside diameter (OD) drill rod segments, as indicated in Figure 2.

\subsubsection{Mast Horizontal Force}

The lower end of the MVDSS mast will be subjected to a horizontal cyclical load induced by the effluent from the tank mixer pumps. The actual horizontal cyclical end load on the MVDSS mast was determined in two ways:

- Reviewing an existing analysis and

- Observation of actual deflections of existing equipment deployed in a tank with operating mixer pumps.

The analysis Evaluation of the Effect of Project W-151 Mixer Pump Jets on In-Tank Equipment Considering Potential Sludge Buildup on Equipment in Waste Tank 241-AZ-101, Hanford Site, Richland, Washington (FDNW, 1997) determined the pump jet forces on various in-tank equipment by the use of a 1/6 scale model. The analysis contained in FDNW 1997 was modified to determine the jet pump forces on the MVDSS mast. Figure 7 shows a graph of the horizontal force on the MVDSS mast vs. distance from the Jet Pump for various thickness of sludge that could buildup on the mast.

Based on the revised analysis from FDNW 1997, the maximum force expected from the mixer pump is approximately $200-\mathrm{lbs}$ for a mast will be placed no closer than $14.5-\mathrm{ft}$. from the mixer pump,.

The second analysis used actual operational deflection data obtained from the 241-AZ-101 mixer pump test. This test aimed the mixer pump directly at a 6-in. Dry Well located approximately $10-\mathrm{ft}$. from the mixer pump. The mixer pump was then started and the pump speed increased as the deflection of the Dry Well was observed. At 857 RPM, the Dry Well was observed to deflect 1.9-in. at the Dry Well, tank waste interface. Based on this data, the actual force on the Dry Well was determined to be $39.5-1 b s$. At $110 \%$ of rated pump RPM, the maximum force on the Dry Well was determined to be 50.7-lbs.

Since the cyclical horizontal force data from the theoretical analysis significantly differs from the actual in-tank deflection data, a logical, final force level needed to be chosen. The horizontal cyclical force was chosen to be $120-\mathrm{lb}$. This force is $60 \%$ smaller than the theoretical loading from FDNW 1997 but is $237 \%$ larger than the forces from the above in-tank analysis. 


\subsubsection{Minimum Allowable Bend Radius}

As indicate above, the mast may be subjected to a cyclical horizontal end loading from the mixer pump effluent. In order for the mast internal components to move freely up and down, a minimum bend radius for the mast was be specified.

The minimum allowable bend radius for the mast was determined in the following manner:

1.) The cyclical horizontal end loading was applied to the mast.

2.) The location of the largest moment was determined (at the riser bottom).

3.) The bend radius at that location was calculated.

The calculations determined that minimum bend radius is $176-\mathrm{ft}$.

\subsubsection{Segmented Mast Fatigue Strength}

In order to determine the fatigue strength of the mast two items must be known; the number of cycles and the maximum cyclical stress. Given that the life span of a mixer pump is approximately 5000-hours and that the mixer pump rotates through a 180-degree span at about 0.1 revolutions/minute the number of cycles is determined by multiplication of the life span times the number of cycles per minute (in the proper units). This results in a 30,000 cycles. The maximum cyclical stress due to the 120 -lb end cyclical end load occurs 48 -feet from the bottom of the mast. Knowing this information and that the section modulus of the mast is 1.72in $^{3}$, the maximum cyclical stress was calculated to be 40,186 -psi.

Since the number of stress cycles is greater than $10^{3}$ this is considered high-cycle fatigue. From Figure 7-3, Page 273 of Shigley and Mitchell 1983 and given that the mast will be constructed from 4130 steel, the endurance limit is approximately 49,000-psi. Since the endurance limit is greater than the maximum cyclical stress, the mast will not fail due to fatigue. 


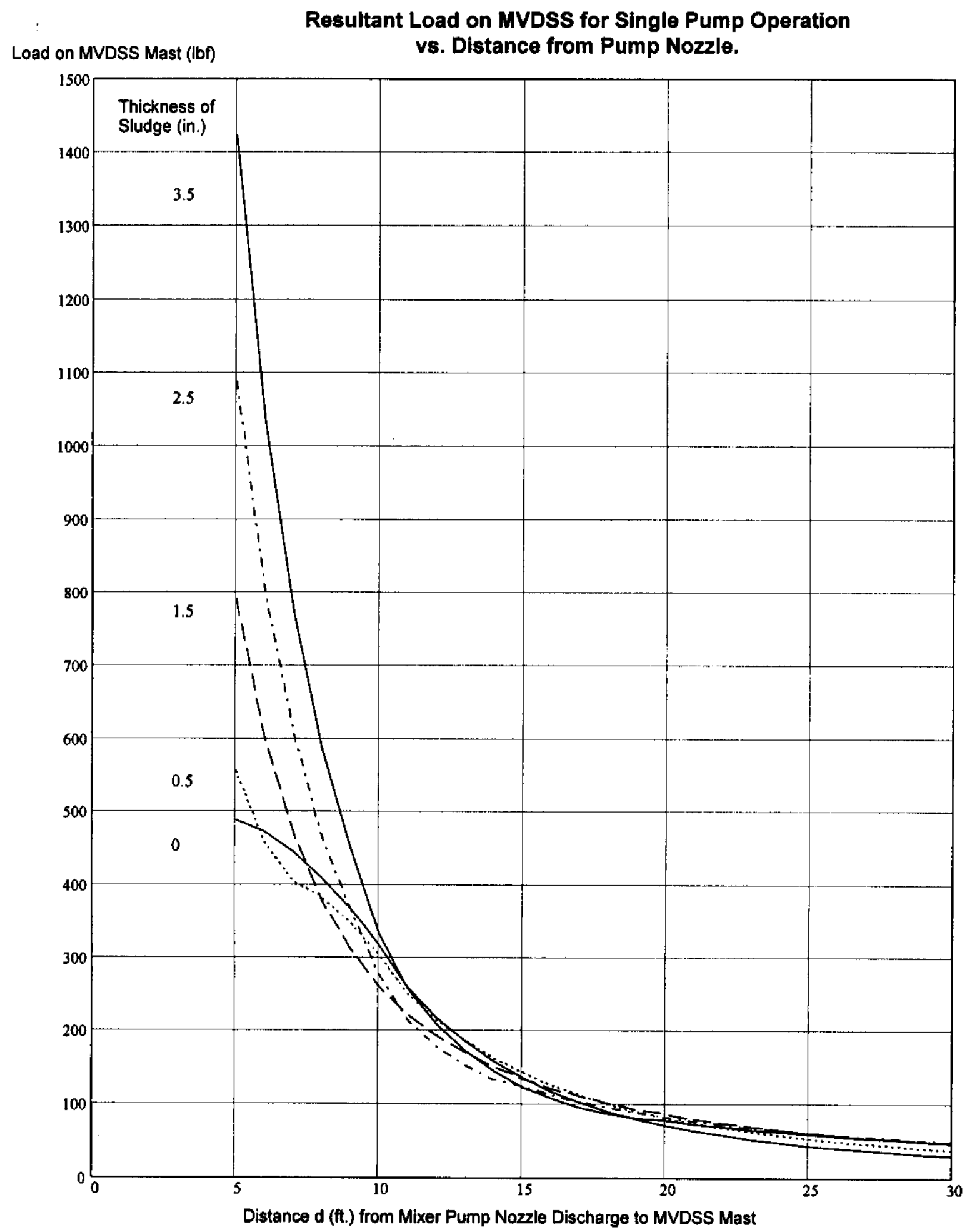

Figure 7 Graph of horizontal force vs. distance for various sludge buildup thickness levels. 


\subsection{Tank Riser and Dome Load Limits}

The MVDSS will be setup over a tank riser so that its total weight is supported by the tank dome structure. The mast will impart some vertical and horizontal loads to the tank riser. The horizontal loading will be from the impact of the mixer pump effluent impacting the bottom of the mast structure when the mixer pumps are operating.

The information in Table 1 lists the currently allowable loads that can be safely supported by each of the feed tanks for the Phase 1 Case 3S6 waste feed staging sequence. These total load limits were obtained from the Cognizant Engineer for each Tank and/or the applicable 200 East or 200 West Area Shift Office. It should be noted that Tank Farms requires that a Tank Dome Loading Calculation be completed prior to the placement of any temporary equipment over the dome area of a waste tank. The load limits in Table 1 do not include temporary loads.

Mixer pump force calculations indicate that the in-tank mast structure will be subjected to a 120-lb cyclic horizontal load one foot from the bottom of the tank caused by the action of the tank mixer pumps. This cyclical horizontal load is based on the mast being located, at all times, no closer than 10 -ft from the tank mixer pump outlet nozzle.

It has been Characterization Engineering's experience that inclusion of temporary loads and using the lowest allowable load limit will result in a maximum usable load of approximately 30,000 -lbs for a sampling system.

The following load limits are based on this data:

- The maximum allowed vertical load that could be transferred to the tank riser is less than 2,200-lbs.

- The maximum moment that could be imparted to the top of the riser is less than $6,400-\mathrm{ft}-\mathrm{lbs}$.

- In no case will the sampling system impart loads to the tank riser that exceed $10 \%$ of these riser limits.

- The maximum load on the tank dome from all of the sampling system hardware is less than or equal to $30,000-\mathrm{lbs}$. This load limit is based on Characterization Engineering's sampling experience. A larger load limit may be feasible, however, it is not recommended. Before setup of sampling system hardware, a tank dome loading calculation would be completed to ensure that the allowable tank dome loading is not exceeded by the addition of temporary equipment. 
Table 1 Waste feed tank (Case 3S6) and corresponding allowable dome loading

\begin{tabular}{|c|c|}
\hline Tank & $\begin{array}{c}\text { Total Allowable Load } \\
\text { (lbs) }\end{array}$ \\
\hline $241-$ AP-101 & 157,013 \\
\hline $241-$ AN-102 & 164,118 \\
\hline $241-$ AN-104 & 164,118 \\
\hline $241-A N-107$ & 164,118 \\
\hline $241-\mathrm{AN}-105$ & 164,118 \\
\hline $241-\mathrm{SY}-101$ & 70,000 \\
\hline $241-\mathrm{AN}-103$ & 164,118 \\
\hline $241-\mathrm{AW}-101$ & 164,118 \\
\hline $241-\mathrm{AP}-102$ & 164,118 \\
\hline $241-\mathrm{AP}-104$ & 164,118 \\
\hline $241-\mathrm{AN}-101$ & 164,118 \\
\hline $241-\mathrm{AZ}-101$ & 96,163 \\
\hline $241-\mathrm{AZ}-102$ & 96,433 \\
\hline $241-\mathrm{AY}-102 /(\mathrm{C}-106)^{*}$ & 164,118 \\
\hline $241-\mathrm{AY}-101 /(\mathrm{C}-104)^{*}$ & 164,118 \\
\hline $241-\mathrm{SY}-102$ & 176,000 \\
\hline
\end{tabular}

*Data for C-106 and C-104

\subsection{Tank Waste Physical, Chemical, and Radiological Properties}

The sampling system will encounter wastes in which it must provide representative samples as well as wastes in which the sampling system must survive and then be able to resume normal sampling operation. The normal operation of the sampling system and the at-tank analysis system is based on the most severe parameters from LAW or HLW. The waste and waste tank environmental parameters are from:

- HNF-1507, Initial Tank Retrieval Systems Data for Waste Transfer System,

- $\quad$ Published Tank Characterization Reports (TCRs), such as WHC-SD-WM-ER411. Rev. 0, Tank Characterization Report for Double-Shell Tank 241-AZ-102.

- $\quad$ SACS Tank Temperature data from the Tank Waste Information Network System (TWINS) data base (network address is http://twins.pnl.gov:8001/twins.htm). 
Representative sampling would be from waste having the following LAW and HLW property ranges:

a.) HLW waste properties:

- Temperature range: $50^{\circ} \mathrm{F}$ to $200^{\circ} \mathrm{F}$

- $\mathrm{pH}$ :

8 to 14

- Specific Gravity:

- Liquid - 1.2 to 1.4

- Slurry - 1.1 to 1.55

- Viscosity: 10 Centipoise (cp) (Non-Newtonian)

- Radioactivity $500 \mathrm{rad} / \mathrm{hour}\left(2.2 \times 10^{07} \mathrm{rads}\right.$ over 5 years $)$

- Particle size (also see Appendix B, Level 2 Component Specification):

$\underline{\text { Size }}$

$>4000 \mu \mathrm{m}$

fraction of total solids

- 50 to $500 \mu \mathrm{m}<5 \mathrm{wt} . \%$

- $<50 \mu \mathrm{m} \quad 94 \mathrm{wt} . \%$

- Solids content: up to $10 \%$ by wt (potential maximum).

- Chemical constituents (see Level 2 Component Specification (Reich, 1999), Appendix A)

b.) LAW properties:

- Temperature range: $50^{\circ} \mathrm{F}$ to $120^{\circ} \mathrm{F}$

- $\mathrm{pH}$ :

8 to 15 .

- Specific Gravity: 1.3 to 1.55

- Viscosity: less than $10 \mathrm{cp}$

- Radioactivity

- Particle size:

Size fraction of total solids

$>4000 \mu \mathrm{m} \quad<1.0 \mathrm{wt} . \%$

- 500 to $4000 \mu \mathrm{m}<1.0 \mathrm{wt} . \%$

- 50 to $500 \mu \mathrm{m} \quad 50 \mathrm{wt} . \%$

- $<50 \mu \mathrm{m} \quad 50 \mathrm{wt} . \%$

- Solids content: up to $2 \mathrm{wt} \%$

- Chemical composition: (see Level 2 Specification (Reich, 1999) Appendix

A)

The sampling system could contact wastes having properties that are outside of the ranges of the LAW and HLW that is to be representative sampled. The sampling system should be capable of surviving this more severe waste environment and then resume normal, representative sampling operations with the LAW and HLW having the above properties. The resumption of normal sampling operations would be accomplished without requiring special containment or containment intrusive maintenance and without replacement of sampling system 
components. Sampling at any performance level with wastes having these more severe physical properties is desired/preferred but is not a requirement for the sampling system.

c.) LAW and HLW waste parameters in which the sampling system would survive and then resume normal LAW and HLW sampling include:

- Temperature range: $50^{\circ} \mathrm{F}$ to $260^{\circ} \mathrm{F}$

- $\mathrm{pH}$ : 8 to 15

- Specific Gravity: 1.8

- Viscosity: $50-60 \mathrm{cp}$

- Radioactivity $>2,000 \mathrm{rad} / \mathrm{hour}\left(2.2 \times 10^{07}\right.$ rads over 5 years $)$

- Particle size: $\quad<50 \mu \mathrm{m}$ to $>4000 \mu \mathrm{m}$

- Solids content: $30-35 \mathrm{wt} \%$

- Chemical-composition: (see Level 2 Specification (Reich, 1999) Appendix A)

\subsection{Dome Space (Physical and Chemical) Environment}

All sampling system components that are in the waste tank but reside in the air space above the waste would encounter the following ranges of environmental conditions:

- Temperature range:

- Relative humidity:

- Radiological: HNF-Appendix C)

- Dripping liquid from dome

- Aerosols and airborne waste solids and liquids.

The specific chemical environment for airborne waste solids and liquids are defined in the Best Basis Inventory (database) for each waste tank.

\subsection{Tank Farm (Above Grade) Environment}

The components and modules that reside above grade level over the waste tank would encounter the following ranges of environmental conditions:

- Temperature Range:
- Operating: $\quad-15$ to $120^{\circ} \mathrm{F}$

- Non-operating (system in standby): -20 to $150^{\circ} \mathrm{F}$

- Relative humidity: 4 to $100 \%$

- Wind speed: Maximum of $85 \mathrm{mph}$, standby condition, $25 \mathrm{mph}$ maximum operating condition, average of $8.8-\mathrm{mph}$. 
- Moisture:

- Rainfall up to 2 -in/hr, annual average precipitation of 6.3 -in.

- Snow accumulation of up to $2-\mathrm{ft}$, snowfall loading of $15-\mathrm{lb} / \mathrm{ft}^{2}$.

- Dust: Capable of withstanding blowing sand and dust, and volcanic ash fallout, ashfall loading of $30-\mathrm{lb} / \mathrm{ft}^{2}$.

- Dose rate of $0.5-\mathrm{mR} / \mathrm{hr}$.

\subsection{Fluidic Pump Design Envelope Parameters for 4.0-Inch Riser Deployment}

The Case 3S6 Phase 1 feed tanks have slightly different dimensions that includes the height from the bottom of the tank to the top of the riser flange. The mast would be deployed in a 4-in riser, as indicated in Section 3.7. Table 2 shows the parameters for sampling in these feed tanks. Column 2 of Table 2 shows the AEAT fluidic pump data that has been confirmed by testing and by model calculations. Column 3 shows the parameters that will be required by the system for sampling the feed tanks. Additional dimensional parameters include the following:

- 58- $\mathrm{ft}$ maximum distance from tank bottom to the top of a riser.

- 4-in tank riser. However, the free diameter inside the tank riser will be between 3.5 to 4-inches.

- 1-ft. (empty) to 35-ft. (full tank) tank waste depth range.

- 23-ft maximum distance from the bottom of the riser to the waste

- The above ground, surface space around the tank riser that is available for the sampling system is a circle with a diameter less than 10-ft. (Note: The support utilities modules, such as the power and compressor skids, may be located outside of the tank farm or in another area adjacent to the feed tank.).

- $70-\mathrm{ft}$ maximum waste lift provided by the sampling system.

- $90-\mathrm{ft}$ maximum piping length between the charge vessel and the bottle filling station

- The desired inside diameter of the exit hose from the charge vessel is $5 / 8$-inch.

The 90-ft length of pipe includes a $70-\mathrm{ft}$ lift and 20 - $\mathrm{ft}$ horizontal distance, as indicate in Table 2. This is the anticipated maximum pipe length between the RFD and the sample bottle filling station where the $500-\mathrm{mL}$ sample bottles will be filled.

Figure 8 shows a cross-section of a conceptual mast and charge vessel deployed in a 4-in riser inside a mast. A 2.75-inch maximum outside-diameter charge vessel would provide a total clearance space of 0.25 -inch between the charge vessel and the inside-diameter of the drill string mast. The cross-section area included in Figure 8 is the calculated area in the charge vessel that would be occupied by tank waste. The cable tube, that passes through the charge vessel, carries the cable that will be used to pull the charge vessel downward, providing positive vertical (elevation) placement of the charge vessel RFD inlet for sample acquisition. The "flats" on the sides of the charge are representative of features that will prevent the charge vessel from rotating inside the mast so that the RFD is "pointed" at the slot in the drill string segments. 
Table 2 Fluidic pump design parameters

\begin{tabular}{|l|c|c|}
\hline Function & $\begin{array}{c}\text { AEAT - Base data on } \\
\text { simulations }\end{array}$ & $\begin{array}{c}\text { CHG Team - Parameters required to fit inside a } \\
\text { mast that can be deployed in a 4-inch tank riser. }\end{array}$ \\
\hline Drive pressure & $4.2-\mathrm{Barg}$ & TBD \\
\hline Suction pressure & $4.2-\mathrm{Barg}$ & TBD \\
\hline Vertical Pipe Length & $18.0-\mathrm{m}$ & $70-\mathrm{ft}(21.3-\mathrm{m})$ \\
\hline Horizontal Pipe Length & $2.0-\mathrm{m}$ & $20-\mathrm{ft}(6.1-\mathrm{m})$ \\
\hline Density of Fluid & $1400-\mathrm{kg} / \mathrm{m}^{3}$ & (See waste physical property tables) \\
\hline Waste Viscosity & & $10-\mathrm{cp}($ See waste physical property tables) \\
\hline $\begin{array}{l}\text { Charge vessel diameter, } \\
\text { ID }\end{array}$ & $0.063-\mathrm{m}$ & $2.75-$ in $(0.06985-\mathrm{m})$ maximum outside diameter ${ }^{(1)}$ \\
\hline Charge vessel length & $3.6-\mathrm{m}$ & TBD \\
\hline Pipe Diameter & $19.05-\mathrm{mm}$ & $5 / 8-$ inch $(15.9-\mathrm{mm})$ maximum hose inside diameter \\
\hline & & \\
\hline
\end{tabular}

Notes: (1) This is the outside envelope that the mast, which will deploy in a 4-inch tank riser, will accommodate. A deployment cable and the exit piping from bottom of the charge vessel must be inside this diameter limit. The conceptual design drawings of the mast and charge vessel cross-sections show additional dimensional details.

(2) This is the hose that connects to the bottom of the charge vessel that will connect the charge vessel with the sample container filling hardware and will be wrapped around the drum in the sampling system module. 


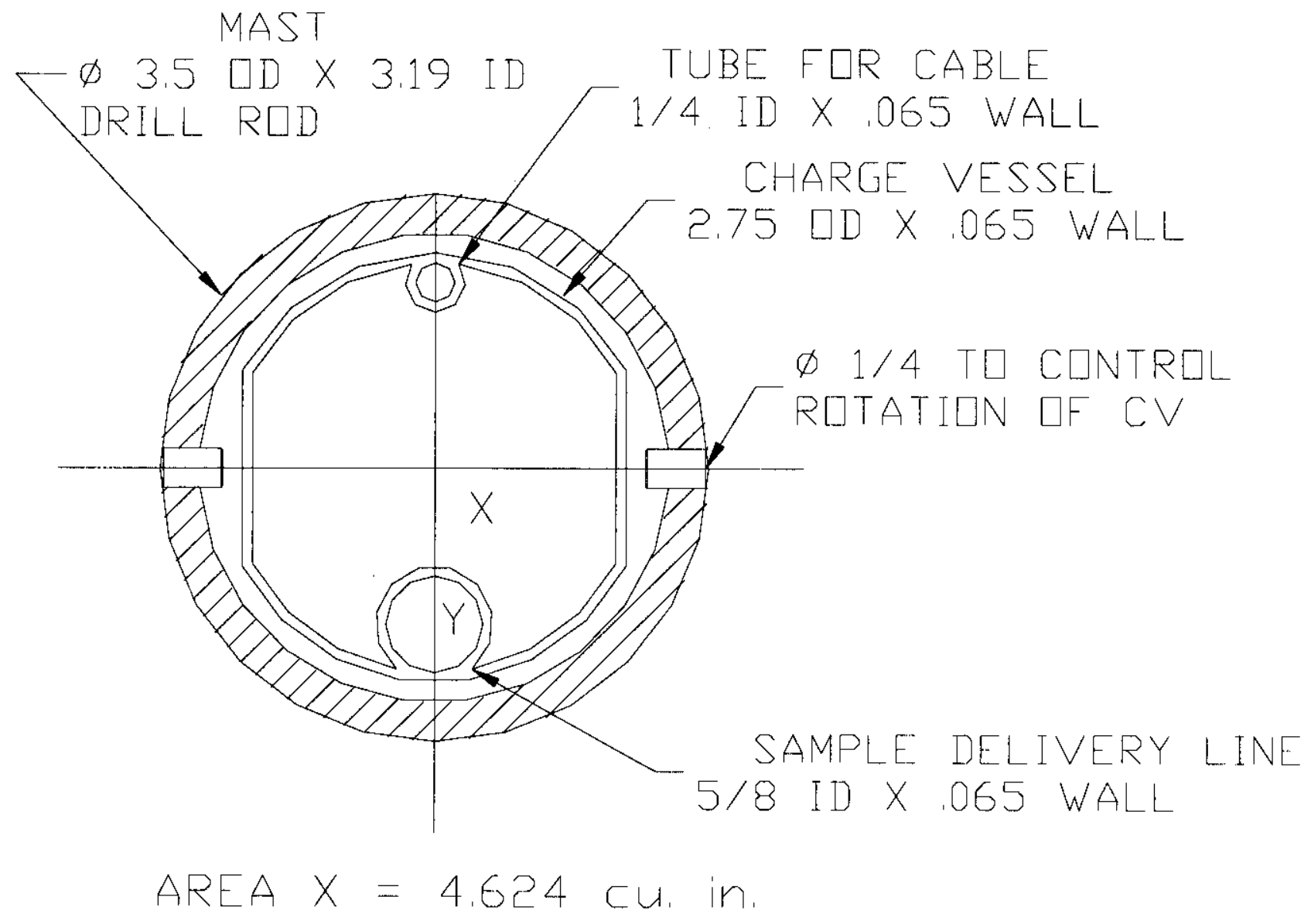

Figure 8 Cross-section of mast and charge vessel for 4-inch riser deployment showing integrated cable and piping. 


\subsection{Tank Riser Size Availability}

Table 3 shows the riser availability data for the Case 3S6 LAW and HLW DST feed tanks. The basis for the data in Table 3 and for assessing riser size and availability includes the following:

- 16 waste tanks identified in R.T. French letter, 00-OPD-013, CONTRACT NO. DEAC06-99RL14047 - MODIFICATION OF FEED DELIVERY SEQUENCE, January 26, 2000.

- Case 3S6, Phase $1 \mathrm{LAW}$ and HLW feed tank sequence (Kirkbride, 2000).

- Current and planned riser occupancy status and the available surface space around a riser

A sampling system foot-print of 10 - $\mathrm{ft}$ diameter was also assumed based on:

- Interference with other risers, deployed hardware, and pits.

- Hanford H-2 tank drawings, such as H-14-010501, Dome Penetration Schedules (WST/WSTA) Tank 241-AN-101.

- 14-ft minimum distance to the nearest mixer pump

- Riser and mixer pump data from the current schedule for mixer pump deployment.

- Limits the force on the deployed mast from the mixer pump effluent

Appendix A, Table A-1 that shows the risers in which mixer pumps are planned to be deployed for each of the Phase 1, Case 3S6 staging tanks. Table 3 contains the following columns of data:

1. Name of the Case 3S6 Phase 1 LAW or HLW tank

2. Size of riser available for deploying the sampling system (inches)

3. Available riser number

4. Risers (riser number) that will contain mixer pumps

5. Distance (feet) from the riser containing the mixer pumps to the riser that the sampler may be deployed (RAD is radius in feet)

6. General notes about the riser.

7. Waste type (low activity waste or high level waste)

The conclusions of this riser assessment for the Case 3S6 feed sequence are:

- 13 of the planned 24 batches for Phase 1 pass through one of the AN tanks that have only 4-inch risers available for deploying a sampling system.

- 7 of the $16 \mathrm{LAW}$ and HLW tanks only have 4-inch risers available for deploying a sampling system. These include AN-101, -102, -103, -104, -105, and SY-101, -102. Tanks. The remaining tanks have potentially larger available risers.

- 7 of the 16 tanks have 6- or 12-inch riser(s) available - AP-101, -102, -104, AY$101,-102$, and $A Z-101,-102$

- AN-107 - 12 inch available if the camera assembly can be moved

- AW-101 - 12 inch available are $<14.5 \mathrm{ft}$ from mixer pump that may produce excessive bending forces on a mast from the nearest mixer pump. 
To support the WFD needs, the MVDSS should be deployable and operable in a 4-inch waste tank riser.

Table 3 Available Phase 1 Case 3S6 LAW and HLW tank risers for MVDSS deployment

\begin{tabular}{|c|c|c|c|c|c|c|}
\hline TANK & $\begin{array}{c}\text { RISER } \\
\text { SIZE }\end{array}$ & \begin{tabular}{|c|} 
RISER \\
NUMBER
\end{tabular} & $\begin{array}{c}\text { MIXER } \\
\text { PUMP } \\
\text { RISER }\end{array}$ & $\begin{array}{c}\text { RISER } \\
\text { DISTANCE } \\
\text { FROM PUMP } \\
\text { (feet) }\end{array}$ & NOTES & $\begin{array}{l}\text { WASTE } \\
\text { TYPE }\end{array}$ \\
\hline \multirow[t]{3}{*}{ AN-101 } & 4 & -016 & 007,008 & $25,42.7$ & & \multirow[t]{2}{*}{$\overline{L A W}$} \\
\hline & 4 & -021 & & $30,39.6$ & & \\
\hline & 12 & -013 & & 11,29 & $\begin{array}{l}\text { OBSERVATION PORT, NEXT } \\
\text { CENTRAL PUMP PIT. }\end{array}$ & \\
\hline \multirow[t]{2}{*}{$\mathrm{AN}-102$} & 4 & -017 & 007,008 & $14.6,45.8$ & & LAW \\
\hline & 12 & -013 & & 11,29 & \multicolumn{2}{|l|}{$\begin{array}{l}\text { OBSERVATION PORT, NEXT TO } \\
\text { CENTRAL PUMP PIT. }\end{array}$} \\
\hline \multirow[t]{2}{*}{$\mathrm{AN}-103$} & 4 & -020 & 007,008 & $14.6,46.9$ & & LAW \\
\hline & 12 & -013 & & 11,29 & \multicolumn{2}{|c|}{$\begin{array}{l}\text { OBSERVATION PORT, NEXT TO } \\
\text { CENTRAL PUMP PIT. }\end{array}$} \\
\hline \multirow[t]{2}{*}{ AN-104 } & 4 & -021 & 007,008 & $30,39.6$ & & \multirow[t]{2}{*}{ LAW } \\
\hline & 12 & -013 & & 11,29 & $\begin{array}{l}\text { SPARE OBSERVATION } \\
\text { PORT }\end{array}$ & \\
\hline \multirow[t]{2}{*}{ AN-105 } & 4 & -021 & 007,008 & $30,39.6$ & & LAW \\
\hline & 12 & -013 & & 11,29 & \multicolumn{2}{|c|}{$\begin{array}{l}\text { OBSERVATION PORT, NEXT TO } \\
\text { CENTRAL PUMP PIT. }\end{array}$} \\
\hline \multirow{4}{*}{ AN-107 } & 12 & -009 & NONE & 20 (RAD) & CAMERA ASSEMBLY & LAW \\
\hline & 12 & -013 & & 9 (RAD) & \multicolumn{2}{|c|}{$\begin{array}{l}\text { OBSERVATION PORT, NEXT TO } \\
\text { CENTRAL PUMP PIT. }\end{array}$} \\
\hline & 42 & -007 & & 20 (RAD) & & \\
\hline & 42 & -008 & & 20 (RAD) & & \\
\hline \multirow[t]{7}{*}{ AP-101 } & 4 & -021 & TBD & 28 (RAD) & & \multirow[t]{7}{*}{$\overline{\mathrm{LAW}}$} \\
\hline & 12 & -010 & & 20 (RAD) & & \\
\hline & 12 & -011 & & 30 (RAD) & & \\
\hline & 12 & -012 & & 30 (RAD) & & \\
\hline & 12 & -018 & & 30 (RAD) & & \\
\hline & 12 & -019 & & 30 (RAD) & & \\
\hline & 12 & -020 & & 30 (RAD) & & \\
\hline \multirow{7}{*}{$\begin{array}{l}\text { AW- } \\
101\end{array}$} & 4 & -011 & 007,008 & $21.5,44.5$ & & LAW \\
\hline & 12 & -013 & & 9 & \multicolumn{2}{|l|}{$\begin{array}{l}\text { OBSERVATION PORT, NEXT TO } \\
\text { CENTRAL PUMP PIT. }\end{array}$} \\
\hline & 12 & -023 & & 11,29 & & \\
\hline & 12 & -024 & & $11.9,49.3$ & & \\
\hline & 20 & -025 & & $38.6,40$ & & \\
\hline & 20 & -026 & & $38.6,37$ & & \\
\hline & 36 & -027 & & $35.4,41.2$ & & \\
\hline
\end{tabular}




\begin{tabular}{|c|c|c|c|c|c|c|}
\hline TANK & $\begin{array}{l}\text { RISER } \\
\text { SIZE }\end{array}$ & $\begin{array}{c}\text { RISER } \\
\text { NUMBER }\end{array}$ & $\begin{array}{l}\text { MIXER } \\
\text { PUMP } \\
\text { RISER }\end{array}$ & $\begin{array}{c}\text { RISER } \\
\text { DISTANCE } \\
\text { FROM PUMP } \\
\text { (feet) }\end{array}$ & NOTES & $\begin{array}{l}\text { WASTE } \\
\text { TYPE }\end{array}$ \\
\hline \multirow[t]{7}{*}{ SY-101 } & 4 & -006 & 007,008 & $20,34.6$ & & \multirow[t]{7}{*}{$\overline{L A W}$} \\
\hline & 4 & -011 & & $25,41.8$ & & \\
\hline & 4 & -012 & & $25,41.8$ & & \\
\hline & 4 & -021 & & $20,34.6$ & & \\
\hline & 4 & -022 & & $22.4,22.4$ & & \\
\hline & 12 & -005 & & 17,23 & IN CENTRAL PUMP PIT & \\
\hline & 12 & -014 & & 11,29 & & \\
\hline \multirow[t]{10}{*}{ AP-104 } & 4 & -021 & -013 & 28 & & \multirow[t]{10}{*}{$\overline{\mathrm{LAW}}$} \\
\hline & 4 & -026 & & 15 & & \\
\hline & 4 & -027 & & 15 & & \\
\hline & 4 & -028 & & 15 & & \\
\hline & 4 & -029 & & 33 & & \\
\hline & 12 & -009 & & 20 & & \\
\hline & 12 & -011 & & 30 & & \\
\hline & 12 & -018 & & 30 & & \\
\hline & 12 & -019 & & 30 & & \\
\hline & 12 & -020 & & 30 & & \\
\hline \multirow[t]{10}{*}{$\mathrm{AP}-102$} & 4 & -021 & -013 & 28 & & \multirow[t]{10}{*}{$\overline{\text { LAW }}$} \\
\hline & 4 & -026 & & 15 & & \\
\hline & 4 & -027 & & 15 & & \\
\hline & 4 & -028 & & 15 & & \\
\hline & 4 & -029 & & 33 & & \\
\hline & 12 & -009 & & 20 & & \\
\hline & 12 & -011 & & 30 & & \\
\hline & 12 & -018 & & 30 & & \\
\hline & 12 & -019 & & 30 & & \\
\hline & 12 & -020 & & 30 & & \\
\hline \multirow[t]{9}{*}{$\overline{A Y-102}$} & $\overline{4}$ & $-005 \mathrm{~A}$ & $\begin{array}{l}1 \mathrm{~A}, 1 \mathrm{~B}, 1 \mathrm{C}, \\
1 \mathrm{D}\end{array}$ & $10,38.8,38.8,52$ & & \multirow[t]{9}{*}{ HLW } \\
\hline & 6 & $-015 A$ & & $13.7,18,30,33$ & & \\
\hline & 6 & $-015 \mathrm{E}$ & & $\begin{array}{c}9.4,30.3,40.4 \\
49.6\end{array}$ & & \\
\hline & 6 & $-015 \mathrm{G}$ & & $16.3,34,47.4,56$ & & \\
\hline & $\overline{6}$ & $-015 \mathrm{I}$ & & $\begin{array}{c}17.3,32.8,48.2 \\
55.7\end{array}$ & & \\
\hline & 6 & $-015 \mathrm{~K}$ & & $16.3,34,47.4,56$ & & \\
\hline & 6 & $-015 \mathrm{M}$ & & $\begin{array}{c}17.3,32.8,48.2 \\
55.7\end{array}$ & & \\
\hline & 6 & $-015 Q$ & & $\begin{array}{c}17.3,32.8,48.2 \\
55.7\end{array}$ & & \\
\hline & 16 & $-022 \mathrm{~A}$ & & $\begin{array}{c}12,20.1,36.9 \\
40.3\end{array}$ & $\begin{array}{l}\text { CONTAINS LIT, LIMITED } \\
\text { SPACE }\end{array}$ & \\
\hline
\end{tabular}




\begin{tabular}{|c|c|c|c|c|c|c|}
\hline TANK & $\begin{array}{l}\text { RISER } \\
\text { SIZE }\end{array}$ & $\begin{array}{c}\text { RISER } \\
\text { NUMBER }\end{array}$ & $\begin{array}{l}\text { MIXER } \\
\text { PUMP } \\
\text { RISER }\end{array}$ & $\begin{array}{c}\text { RISER } \\
\text { DISTANCE } \\
\text { FROM PUMP } \\
\text { (feet) } \\
\end{array}$ & NOTES & $\begin{array}{l}\text { WASTE } \\
\text { TYPE }\end{array}$ \\
\hline \multirow[t]{8}{*}{$\overline{A Z-101}$} & 4 & $-013 B$ & $-1 \mathrm{~A},-1 \mathrm{C}$ & $27.1,51.6$ & & \multirow[t]{8}{*}{ HLW } \\
\hline & 4 & $-013 \mathrm{C}$ & & $22.6,53.8$ & & \\
\hline & 4 & $-013 \mathrm{D}$ & & $27.1,51.6$ & & \\
\hline & 6 & $-015 \mathrm{~A}$ & & $20.7,54.5$ & & \\
\hline & 6 & $-015 \mathrm{D}$ & & $34.3,47.2$ & & \\
\hline & 6 & $-015 \mathrm{G}$ & & $11.9,56$ & & \\
\hline & 6 & $-015 \mathrm{H}$ & & $29,50.6$ & & \\
\hline & 16 & $-022 \mathrm{~A}$ & & $16.2,51.2$ & SURFACE SPACE & \\
\hline \multirow[t]{11}{*}{$A Z-102$} & $\overline{6}$ & $-015 A$ & $-1 \mathrm{~A},-1 \mathrm{C}$ & $20.7,54.5$ & & \multirow[t]{11}{*}{ HLW } \\
\hline & 6 & $-015 \mathrm{C}$ & & $37.2,44.9$ & & \\
\hline & 6 & $-015 \mathrm{E}$ & & $20.7,54.5$ & & \\
\hline & 6 & $-015 \mathrm{~F}$ & & $14.1,56.6$ & & \\
\hline & 6 & $-015 G$ & & $11.9,56$ & & \\
\hline & 6 & $-015 \mathrm{H}$ & & $29,50.6$ & & \\
\hline & 6 & $-015 \mathrm{I}$ & & $37.2,44.9$ & & \\
\hline & 6 & $-015 \mathrm{~J}$ & & $34.3,47.1$ & & \\
\hline & 6 & $-015 \mathrm{~K}$ & & $20.7,54.5$ & & \\
\hline & 6 & $-015 \mathrm{~L}$ & & $14.1,56.6$ & & \\
\hline & 16 & $-022 \mathrm{~A}$ & & $16.2,51.2$ & SURFACE SPACE & \\
\hline \multirow[t]{5}{*}{ SY-102 } & 4 & -003 & 007,008 & $10.3,38.6$ & & \multirow[t]{5}{*}{ HLW } \\
\hline & 4 & -012 & & $25,41.8$ & & \\
\hline & 4 & -021 & & $20,34.6$ & & \\
\hline & 4 & -022 & & $22.4,22.4$ & & \\
\hline & 12 & -014 & & 11,29 & & \\
\hline \multirow[t]{10}{*}{ AY-101 } & 4 & -032 & $\begin{array}{l}1 \mathrm{~A}, 1 \mathrm{~B}, 1 \mathrm{C} \\
1 \mathrm{D}\end{array}$ & $10,38.8,38.8,52$ & & \multirow[t]{10}{*}{ HLW } \\
\hline & 6 & $-015 A$ & & $13.7,18,30,33$ & & \\
\hline & 6 & $.015 \mathrm{D}$ & & $\begin{array}{c}12.8,40.1,42.1 \\
56.8\end{array}$ & & \\
\hline & 6 & $-015 G$ & & $\begin{array}{c}13.7,37.8,44.3 \\
56.6\end{array}$ & & \\
\hline & 6 & $-015 \mathrm{I}$ & & $\begin{array}{c}17.5,32.4,44.3 \\
56.6 \\
\end{array}$ & & \\
\hline & 6 & $-015 \mathrm{~K}$ & & $16,34,47,56$ & & \\
\hline & 6 & $-015 \mathrm{M}$ & & $16,34,47,56$ & & \\
\hline & 6 & -0150 & & $\begin{array}{c}17.5,32.4,44.3 \\
56.6 \\
\end{array}$ & & \\
\hline & 6 & $-015 Q$ & & $\begin{array}{c}13.7,37.8,44.3 \\
56.6\end{array}$ & & \\
\hline & 16 & $-022 \mathrm{~A}$ & & $\begin{array}{c}8.2,23.5,34.8 \\
41.2\end{array}$ & $\begin{array}{l}\text { CONTAINS LIT, LIMITED } \\
\text { SPACE }\end{array}$ & \\
\hline
\end{tabular}




\subsection{Hanford Steel Pig Sample Carrier}

The filled and capped 500-mL sample bottles will be shipped to the laboratories using the shipping system currently used with the base-line grab sampling. The steel pig provides radiation shielding and structural protection for the glass sample bottles. The samples are currently shipped two at a time on a Hanford Cask Truck (reference Hanford drawing H-274812). The N-55 transport container, that holds the filled sample bottles and shipping enclosures, (reference Hanford drawing H-2-92738) contains an inner drum assembly (reference Hanford drawing H-2-74449) that cradles the Pig Shipping Container in which the Steel Pig Sample Carrier is located.

The Steel Pig Sampler Carrier is loaded with the filled 500-mL sample bottles in the sample bottle filling module. The loading operation includes a "bag-out" to prevent contaminating the inside of the Steel Pig. A drawing of the Steel Pig is shown in Figure 9 (Waste Management Federal Services drawing No. E-F-001). The dimensions in brackets in Figure 10 are the current Steel Pig dimensions in which a filled, capped, and bagged $500-\mathrm{mL}$ bottle is packaged. The maximum dimensions are those that the Steel Pig may have and still potentially fit into the Steel Pig shipping system. The vertical dimension of the Steel Pig must accommodate any special cap that a sample bottle may be sealed with and any excess plastic from the "bag-out" of the sample bottle. At the present time, this modified container does not exist and has not been approved for use.

The weight of the sample pig is currently 82-lbs without the sample bottle. A filed $500-\mathrm{mL}$ sample bottle is estimated to weigh 3-lb. The cover for the sample pig is attached with two $1 / 2$ inch UNC bolts (recommended torque of 5 to $10-\mathrm{ft} l \mathrm{lbs}$ ). The bail on the cover may be used to handle the Steel Pig lid. 
RPP-6735, REV. 0

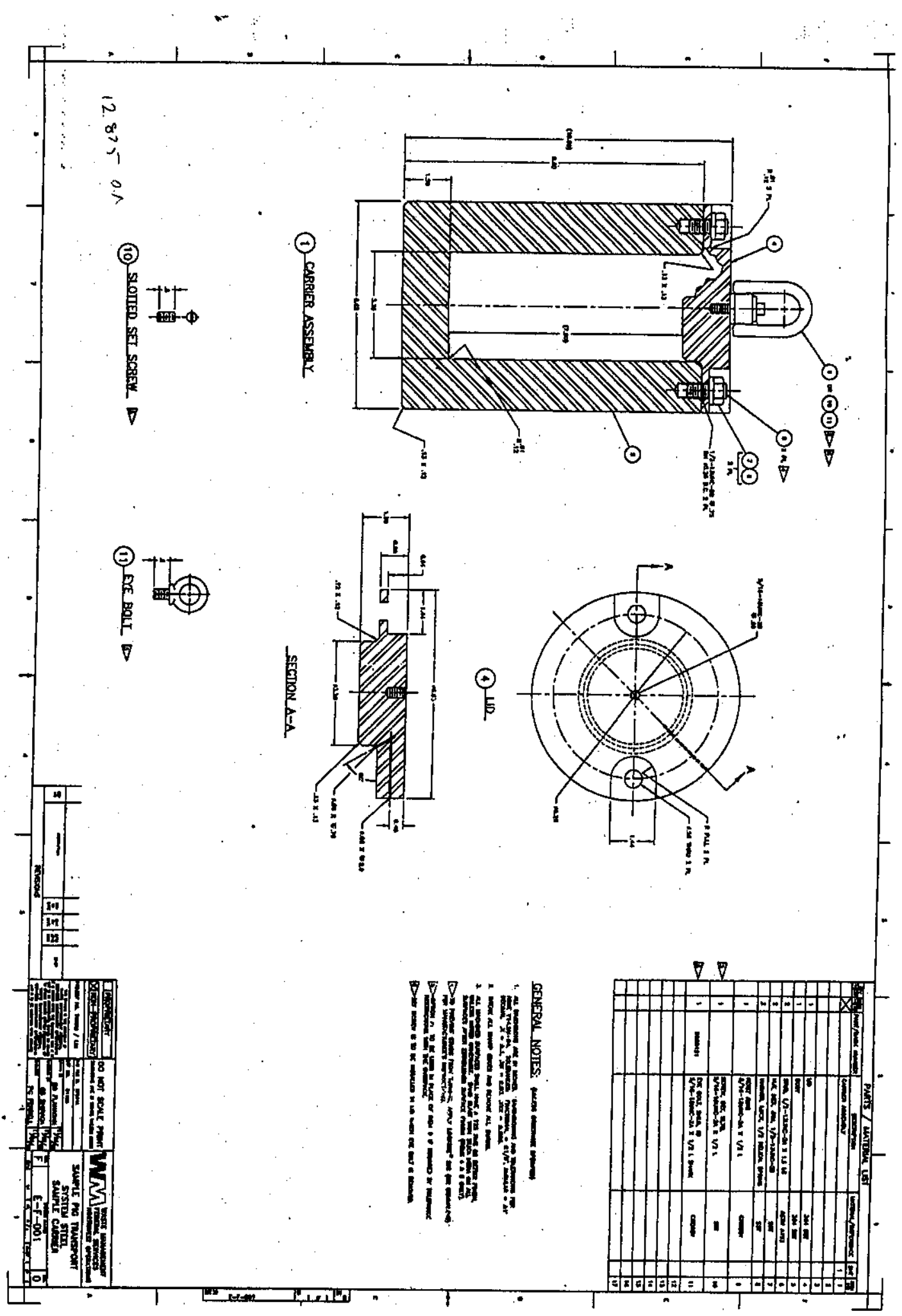

Figure 9 Hanford Steel Pig sample carrier currently used for shipping waste sample bottles, including the $500-\mathrm{mL}$ sample bottle. 
RPP-6735, REV. 0

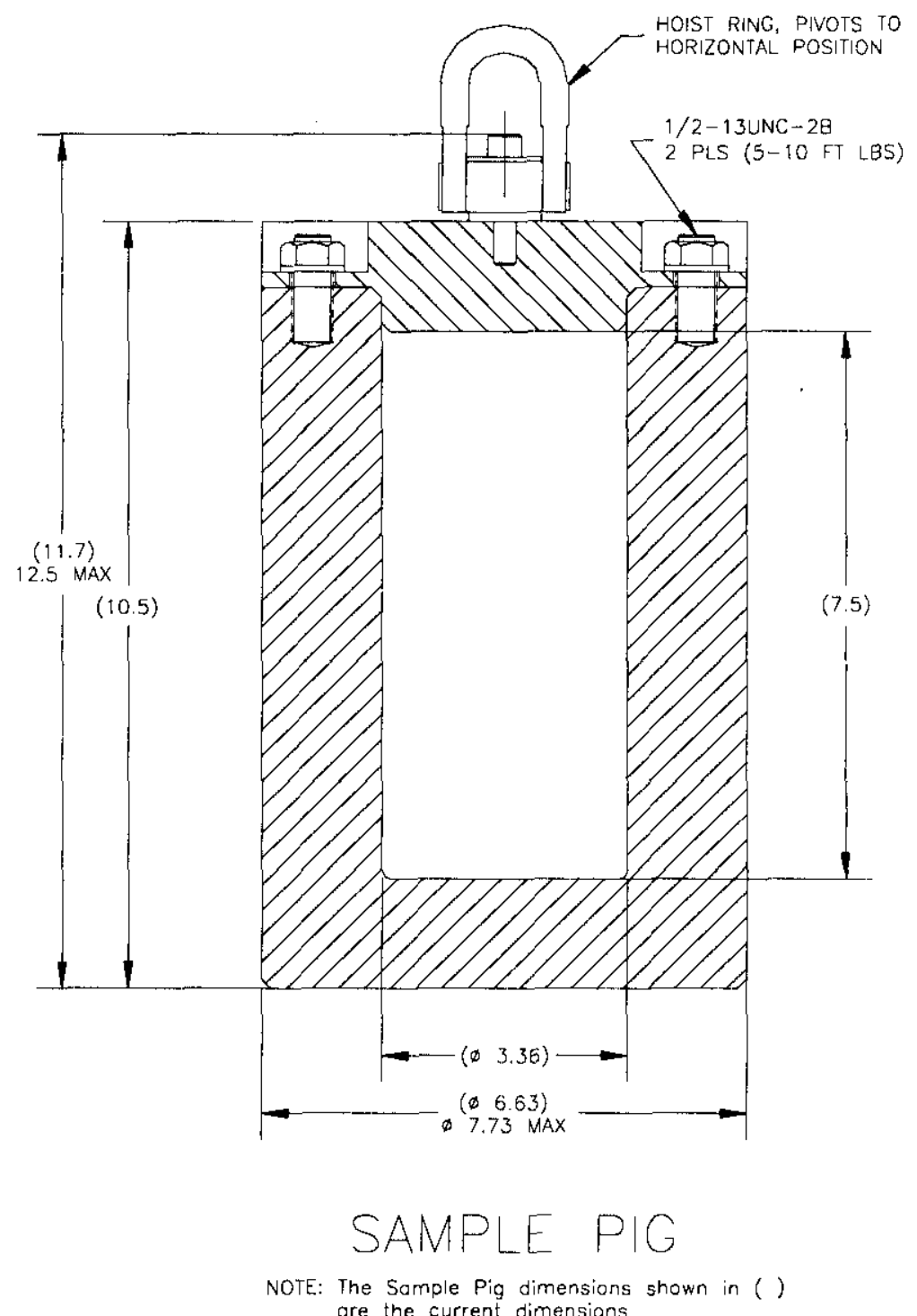

Figure 10 Hanford Steel Pig Sample Carrier showing potential dimensions that would increase radiation shielding. 


\section{$3.9 \quad 500-\mathrm{mL}$ Sample Bottle}

Figure 11 shows the $500-\mathrm{mL}$ sample that is an Owens-Brockway bottle; C-7651 (drawing FR16990-A-2) brown-glass, wide-mouth, 500-ml bottle. The bottle dimensions do not include the bottle cap. The total height of the bottle will depend on the cap that is used in the MVDSS.

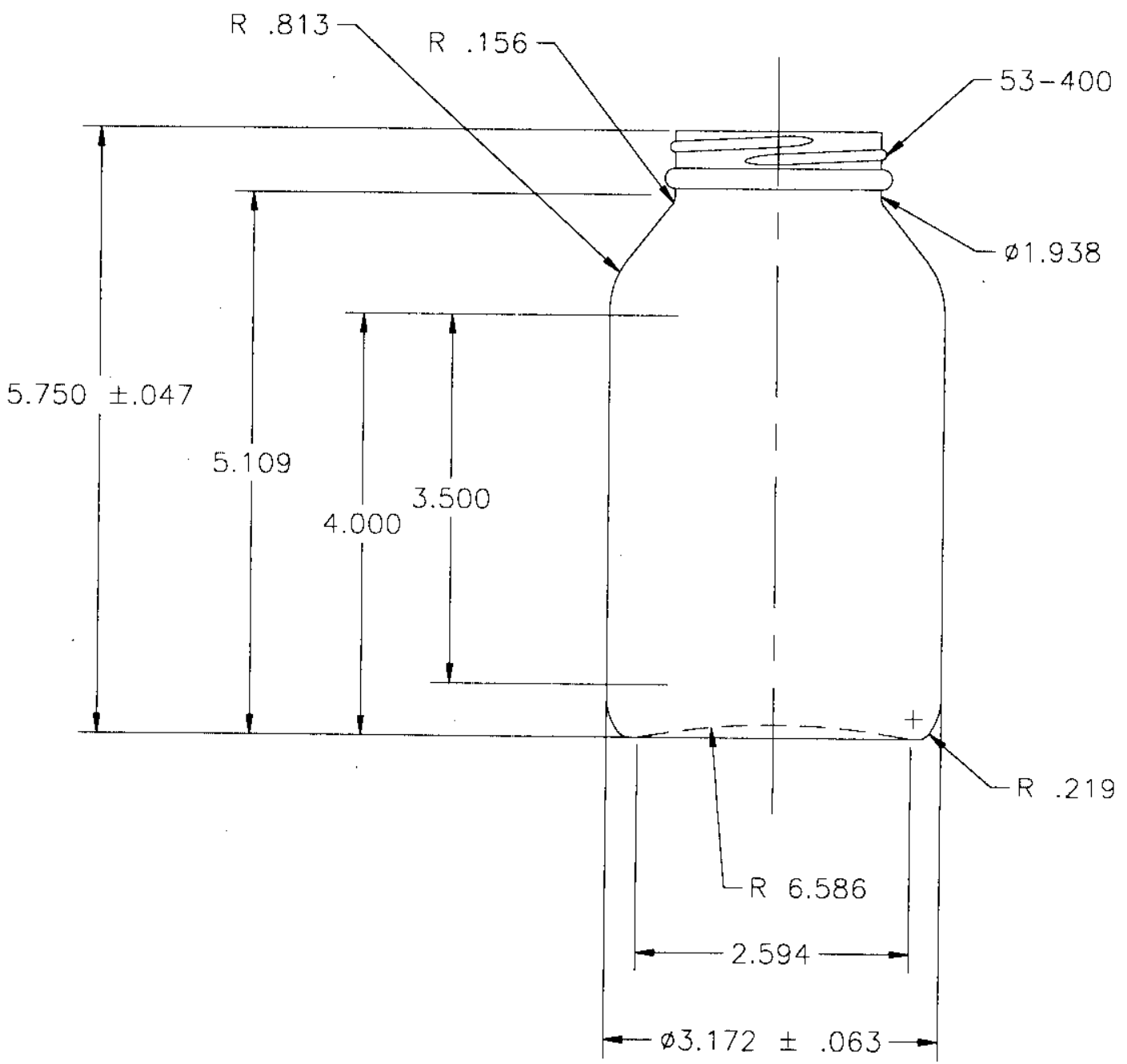

Figure 11 500-mL brown-glass, wide-mouth sample bottle (Owens-Brockway bottle, C-7651 (drawing FR-16990-A-2) 
The lilled and capped (sealed) 500-mL bottle, including the sealed plastic bag (for contamination control), would fit within the inside dimensions of Hanford Steel without the use of insertion forces that could damage the cap or the bottle.

In order to determine the bursting pressure of the 500-ml glass sample bottle a simple linear elastic Finite Element Analysis (Fi:A) model was created as indicate in ligure 12. This mode] assumed that the entire bottle is a uniform $0.1 \mathrm{in}$. thick borosilicate glass. Due to the lack of ductility and the high rate of local irregularities and flaws, the tensile strength of glass rarely exeeds 1000 psi. Given this information, the bursting pressure was conservatively determined to be 10-psi. The bottle manufacturer (Owens Illinois lnc.) was then contacted to verify the sample bottle bursting pressure. Owens Illinois stipulated that this $500-\mathrm{mL}$, bottle is not pressure rated, has no safety coating, and has a burst pressure of approximately 20 -psi.

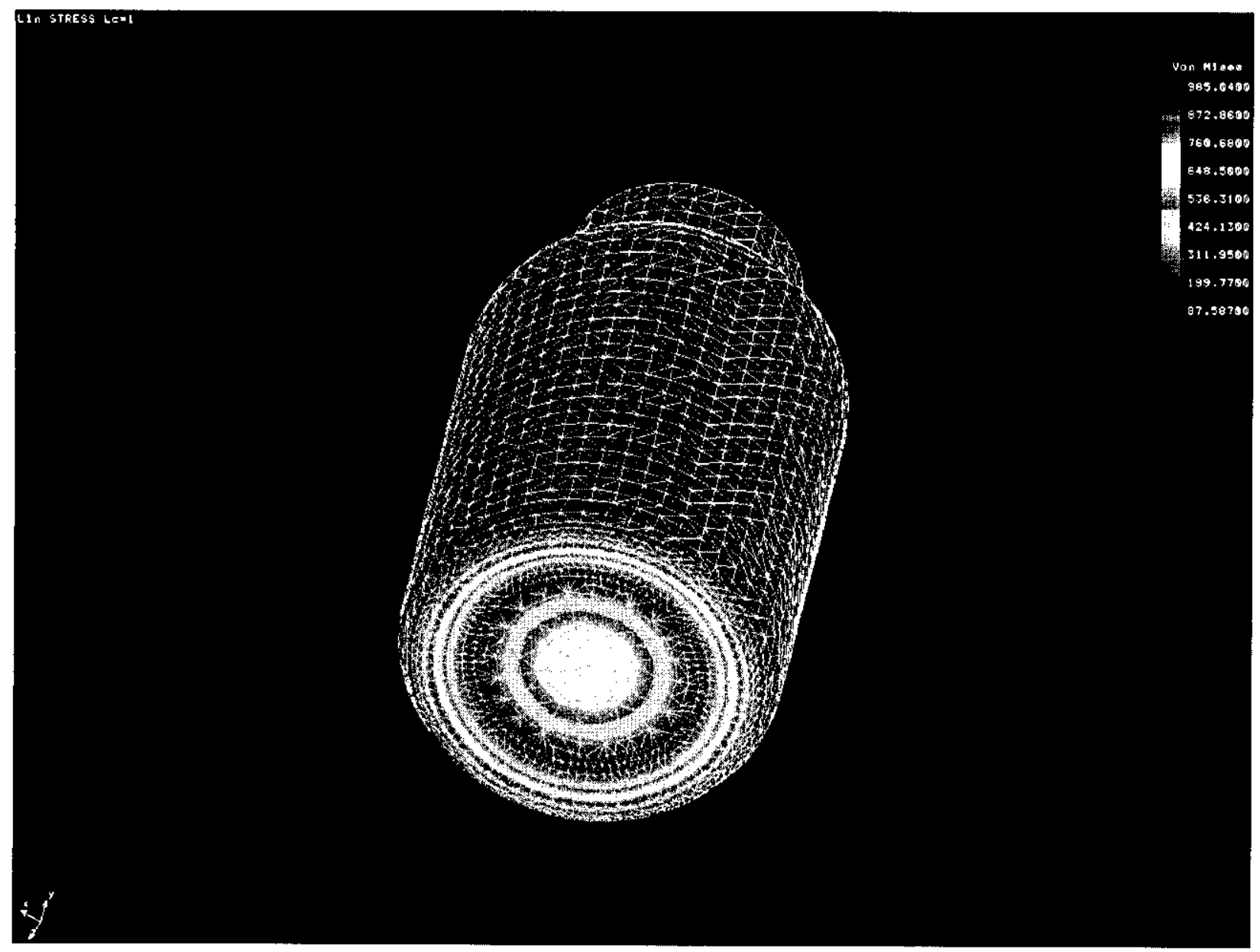

Figure 12 Von Mises stress plot for 10 -psi internal pressure for the 500 -ml, wide-mouth sample bottle. 


\section{Human Engineering}

The MVDSS will have mechanical manipulators, controls, and electrical controls, actuators, and readouts that will be accessed during the operation of the sampling system. The human factor parameters associated with the MVDSS are included in the Level 2 Specification and are based on MIL-Std 1472D and NUREG 0700.

\subsection{Utility Support for Sampling System}

The sampling system requires electrical power, water, and potentially, vacuum/pressure utilities. The primary electrical power, raw water and air/vacuum are provided by portable equipment.

A portable electrical generator provides the primary power for the Mobile Variable Depth Sampler System and the at-tank analysis system. This generator would have an excess, reserve capacity of approximately $25 \%$ above that required to supply all system power requirements.

Tank farm electrical power would be used to support power needs when the system is in an extended standby condition. Only minor upgrades to the utility distribution system may be required to support extended stand by conditions. Major upgrades to the tank farm utilities will not be provided by this project.

The utilities will be mounted on portable trailers that can be easily moved. Two trailers may be needed for this system:

1. Electrical, air and potentially tank farm power conditioning, if needed for standby operation.

2. Flush water system, including reservoir, pump, gauges (flow, pressure, totalizer), and controls. Replenish water with a portable water tank or directly with this trailer.

The umbilicals would be long enough to allow the trailers to be positioned at least $10-\mathrm{ft}$ beyond the edge of a waste tank where their weight will not contribute to the total load on the tank dome.

A portable air pressure system would provide the compressed air for the MVDSS. The vacuum/pressure drive for the fluidic pumping would be provided by a dedicated air-jet system that is not part of these utilities (AEAT furnished system). The air-jet is powered by compressed air and provides the pressure and vacuum power needed to cycle the charge vessel and RFD fluidic pumping system. The compressor system would be mounted on the electrical utility trailer along with the electrical generator.

A portable pressurized water system will probably be used to provide water to the sampling system and the at-tank analysis system for flushing of the piping, hoses and decontamination of equipment. Pressure and flow requirements will be defined during the detailed design. 


\subsection{References}

BNFL-5193-ID-19, Rev. 4e, February 2000, Tank Waste Remediation System Privatization Project, Interface Control Document ICD-19, between DOE and BNFL Inc. for Low Activity Waste, prepared for the U.S. Department of Energy, Richland Operations under Contract DE-AC06-RL13308 by BNFL, Inc., Richland, Washington.

BNFL-5193-ID-20, Rev. 4f, February 2000, Tank Waste Remediation System Privatization Project, Interface Control Document ICD-20, between DOE and BNFL Inc. for HighLevel Waste, prepared for the U.S. Department of Energy, Richland Operations under Contract DE-AC06-RL13308 by BNFL, Inc., Richland, Washington.

HNF-SD-W151-DA-009, Rev. 0, 1997, Evaluation of the Effect of Project W-151 Mixer Pump Jets on In-Tank Equipment Considering Potential Sludge Buildup on Equipment in Waste Tank 241-AZ-101, Hanford Site, Richland, Washington, Fluor Daniel Northwest, Richland, Washington.

Kirkbride, R. A, 2000, Tank Farm Contractor Operation and Utilization Plan, HNF-SD-WM012, Rev. 2, CH2M HILL Hanford Group, Inc. Richland, Washington.

Rassmussen, J. H., 2000, Double-Shell Tank Process Waste Sampling Subsystem Definition Report, RPP-5786, Rev. 0, CH2M HILL Hanford Group, Inc. Richland, Washington.

Rassmussen, J. H, 2000b, Double-Shell Tank Process Waste Sampling Subsystem Specification, HNF-4154, Rev. 0, CH2M HILL Hanford Group, Inc. Richland, Washington

Reich, F. R., 1999, Preliminary Level 2 Specification for the Nested, Fixed-Depth Sampling System, HNF-3483, Rev. 1, prepared by COGEMA for Lockheed Martin Hanford Corporation, Richland, Washington.

Reich, F. R., 1999, Engineering Task Plan for the Development, Fabrication, and Deployment of a Mobile, Variable Depth Sampling and At-Tank Analysis System, HNF-2056, (Rev. 1 or latest revision) prepared by COGEMA for CH2M HILL Hanford Group, Inc. Richland, Washington.

Shigley and Mitchell, 1983, Mechanical Engineering Design, McGraw-Hill Book Company, New York, New York.

Tanks Waste Remediation System Privatization Contract DE-AC06-96RL13308, Mod. No. A006, 1998, U.S. Department of Energy, Richland, Washington. 
RPP-6735, REV. 0

APPENDIX A

\author{
Mixer Pump Data \\ for Phase 1 Case 3S6 \\ LAW and HLW DST Feed Tanks
}




\section{Mixer Pump Data for \\ Phase 1 Case 3S6 LAW and HLW DST Feed Tanks}

Table A-1 shows the mixer pumps that are planned to be deployed in the Case 3S6 Phase 1 LAW and HLW DST feed tanks. This mixer pump data is based on the following:

- HNF-1057 Revision 1, Interface Document Project W-211 Initial Tank Retrieval Systems

- WHC-SD-W151-ER-001 Rev 0, Stress Cycles and Forces on In-tank Components Resulting from Mixer Pump Operation in DST 101-AZ

- W-211-P5, Procurement Spec Waste Mobilization Mixer Pump

- HNF-SD-W151-DA-008, Evaluation of Effect of Project W-151 Mixer Pump Jets on In-Tank Equipment Considering Potential Sludge Buildup on Equipment in Waste Tank 241-AZ-101

The mixer pumps have the following characteristics:

- Each pump has two horizontally opposed (6-inch) diameter outlet nozzles.

- Each nozzle is located 15 to 18 inches off the tank floor.

- Nozzle orientation with respect to the Mixer Pump shaft (and column) centerline will be $90(+5,-0$ degrees) or slightly towards the tank floor ( +5 degrees).

- The design flow capacity for each nozzle is approximately 5,182-gpm such that a velocity diameter product of $29.4-\mathrm{ft}^{\wedge} 2 / \mathrm{sec}$ is achieved.

- The suction inlet will be 8.25 inches from the tank bottom.

- The 150 horse power (hp) pump is identical with the exception of the gpm which is half the $300 \mathrm{hp}$ value.

The columns in table A-1 contain the following information:

1. LAW or HLW DST feed tank

2. Number of pumps to be deployed in the tank

3. Pump size ( 150 or $300 \mathrm{hp})$

4. Nozzle size

5. Nozzle orientation $\left(180^{\circ}\right.$ means that there are two $180^{\circ}$ opposed outlet nozzles).

6. Maximum flow rate for each mixer pump

7. Outlet nozzle height from the bottom of the tank.

8. Tank riser that each pump is deployed in

9. WFD project number. 
Table A-1 Mixer-pumps data for Case 3S6 Phase 1 LAW and HLW DST feed tanks.

\begin{tabular}{|c|c|c|c|c|c|c|c|c|}
\hline TANK \# & \# PUMPS & $\begin{array}{l}\text { PUMP } \\
\text { SIZE (1) }\end{array}$ & $\begin{array}{c}\text { NOZZLE } \\
\text { SIZE }\end{array}$ & $\begin{array}{l}\text { NOZZLE } \\
\text { ORIENT. }\end{array}$ & $\begin{array}{c}\text { FLOW } \\
\text { RATE } \\
\text { PER PUMP } \\
\text { (2.) }\end{array}$ & $\begin{array}{l}\text { HEIGHT } \\
\text { FROM } \\
\text { TANK } \\
\text { BOTTOM }\end{array}$ & $\begin{array}{c}\text { RISER } \\
\text { NUMBER }\end{array}$ & $\begin{array}{c}\text { PROJECT } \\
\#\end{array}$ \\
\hline AP-101 & 0 & No Pump & & & & & & W-521 \\
\hline AP-102 & 1 & $300 \mathrm{hp}$ & $2 @ 6$ inch & $180^{\circ}$ & $11,600 \mathrm{gpm}$ & $\begin{array}{c}15-18 \\
\text { inches }\end{array}$ & 13 & W-521 \\
\hline AP-104 & 1 & $300 \mathrm{hp}$ & $2 @ 6$ inch & $180^{\circ}$ & $11,600 \mathrm{gpm}$ & $\begin{array}{c}15-18 \\
\text { inches }\end{array}$ & 13 & W-521 \\
\hline AP-105 & 1 & $300 \mathrm{hp}$ & $2 @ 6$ inch & $180^{\circ}$ & $11,600 \mathrm{gpm}$ & $\begin{array}{c}15-18 \\
\text { inches }\end{array}$ & 7 or 8 & W-522 \\
\hline AP-106 & 1 & $300 \mathrm{hp}$ & $2 @ 6$ inch & $180^{\circ}$ & $11,600 \mathrm{gpm}$ & $\begin{array}{c}\text { 15-18 } \\
\text { inches }\end{array}$ & 7 or 8 & W-522 \\
\hline AP-108 & 1 & $300 \mathrm{hp}$ & $2 @ 6$ inch & 1800 & $11,600 \mathrm{gpm}$ & $\begin{array}{r}15-18 \\
\text { inches }\end{array}$ & 7 or 8 & W-522 \\
\hline AW-101 & 2 & $300 \mathrm{hp}$ & $2 @ 6$ inch & $180^{\circ}$ & $11,600 \mathrm{gpm}$ & $\begin{array}{c}15-18 \\
\text { inches }\end{array}$ & 7 and 8 & W-521 \\
\hline AW-103 & 2 & $300 \mathrm{hp}$ & $2 @ 6$ inch & $180^{\circ}$ & $11,600 \mathrm{gpm}$ & $\begin{array}{c}15-18 \\
\text { inches }\end{array}$ & 7 and 8 & W-521 \\
\hline AW-104 & 2 & $300 \mathrm{hp}$ & $2 @ 6$ inch & $180^{\circ}$ & $11,600 \mathrm{gpm}$ & $\begin{array}{l}\text { 15-18 } \\
\text { inches }\end{array}$ & 7 and 8 & W-521 \\
\hline AN-101 & 2 & $300 \mathrm{hp}$ & $2 @ 6$ inch & $180^{\circ}$ & $11,600 \mathrm{gpm}$ & $\begin{array}{c}15-18 \\
\text { inches }\end{array}$ & 7 and 8 & W-211 \\
\hline $\mathrm{AN}-102$ & 2 & $300 \mathrm{hp}$ & $2 @ 6$ inch & $180^{\circ}$ & $11,600 \mathrm{gpm}$ & $\begin{array}{l}15-18 \\
\text { inches }\end{array}$ & 7 and 8 & W-211 \\
\hline AN-103 & 2 & $300 \mathrm{hp}$ & $2 @ 6$ inch & $180^{\circ}$ & $11,600 \mathrm{gpm}$ & $\begin{array}{c}15-18 \\
\text { inches }\end{array}$ & 7 and 8 & W-211 \\
\hline AN-104 & 2 & $300 \mathrm{hp}$ & $2 @ 6$ inch & $180^{\circ}$ & $11,600 \mathrm{gpm}$ & $\begin{array}{c}15-18 \\
\text { inches }\end{array}$ & 7 and 8 & W-211 \\
\hline AN-105 & 2 & $300 \mathrm{hp}$ & $2 @ 6$ inch & $180^{\circ}$ & $11,600 \mathrm{gpm}$ & $\begin{array}{c}15-18 \\
\text { inches }\end{array}$ & 7 and 8 & W-211 \\
\hline AN-107 & 0 & No Pump & & & & & & W-211 \\
\hline SY-101 & 2 & $300 \mathrm{hp}$ & $2 @ 6$ inch & $180^{\circ}$ & $11,600 \mathrm{gpm}$ & $\begin{array}{r}15-18 \\
\text { inches }\end{array}$ & 7 and 8 & W-521 \\
\hline$S Y-102$ & 2 & $300 \mathrm{hp}$ & $2 @ 6$ inch & $180^{\circ}$ & $11,600 \mathrm{gpm}$ & $\begin{array}{r}15-18 \\
\text { inches }\end{array}$ & 7 and 8 & W-521 \\
\hline SY-103 & 2 & $300 \mathrm{hp}$ & $2 @ 6$ inch & $180^{\circ}$ & $11,600 \mathrm{gpm}$ & $\begin{array}{c}15-18 \\
\text { inches }\end{array}$ & 7 and 8 & W-521 \\
\hline AY-101 & 4 & $150 \mathrm{hp}$ & $2 @ 6$ inch & $180^{\circ}$ & $7,950 \mathrm{gpm}$ & $\begin{array}{c}15-18 \\
\text { inches }\end{array}$ & $\begin{array}{c}1 \mathrm{~A}, 1 \mathrm{~B}, 1 \mathrm{C} \\
1 \mathrm{D}\end{array}$ & W-521 \\
\hline AY-102 & 4 & $150 \mathrm{hp}$ & $2 @ 6$ inch & $180^{\circ}$ & $7,950 \mathrm{gpm}$ & $\begin{array}{c}15-18 \\
\text { inches }\end{array}$ & $\begin{array}{c}1 \mathrm{~A}, 1 \mathrm{~B}, 1 \mathrm{C} \\
1 \mathrm{D}\end{array}$ & W-521 \\
\hline AZ-101 & 2 & $300 \mathrm{hp}$ & $2 @ 6$ inch & $180^{\circ}$ & $11,600 \mathrm{gpm}$ & $\begin{array}{c}15-18 \\
\text { inches }\end{array}$ & $1 \mathrm{~A}$ and $1 \mathrm{C}$ & W-211 \\
\hline AZ-102 & 2 & $300 \mathrm{hp}$ & $2 @ 6$ inch & $180^{\circ}$ & $11,600 \mathrm{gpm}$ & $\begin{array}{c}15-18 \\
\text { inches }\end{array}$ & $1 \mathrm{~A}$ and $1 \mathrm{C}$ & W-211 \\
\hline
\end{tabular}

Notes: 1.) hp - horse-power

2.) gpm - gallons per minute 
RPP-6735, REV. 0

\section{APPENDIX B}

Tank Waste Temperature Data For

Phase 1 Case 3S6 LAW and HLW DST Feed Tanks 
Tank Waste Temperature Data For

Phase 1 Case 3S6 LAW and HLW DST Feed Tanks

The temperature of the LAW and HLW in the DST varies according to a number factors, including the waste type and age. Table B-1 shows maximum waste temperatures for the Case 3S6 Phase $1 \mathrm{LAW}$ and HLW DSTs. This data was extracted from the SACS Tank Temperature Data contained in the Tank Waste Information Network Systems (TWINS) data base. This data base can be found at network address. The data columns in Table B-1 are:

Waste tank

Maximum waste temperature recorded over a 12 month time period

Minimum waste temperature recorded over a 12 month time period

In-tank thermocouple that produces the maximum waste temperature reading.

In-tank thermocouple that produced the minimum waste temperature reading.

For the LAW, AN-103 and AN-104 have the highest waste temperatures. For HLW, AZ-101 and $A Z-102$ have the highest waste temperatures. The bounding temperature ranges for representative sampling of $\mathrm{HLW}$ and LAW are:

- HLW Temperature range: $50^{\circ} \mathrm{F}$ to $200^{\circ} \mathrm{F}$

- LAW Temperature range: $50^{\circ} \mathrm{F}$ to $120^{\circ} \mathrm{F}$

These bounding temperatures are $20^{\circ} \mathrm{F}$ higher than the highest LAW and HLW temperatures recorded in Table B-1 for the 12 month time period. The bounding temperature range which the sampling system must survive and then resume normal sampling operations is

Temperature range: $50^{\circ} \mathrm{F}$ to $260^{\circ} \mathrm{F}$ 
Table B-1 Maximum and minimum waste temperatures for the Case 3S6 Phase 1 LAW and HLW DSTs recorded over a 12 month period.

\begin{tabular}{|l|r|r|r|r|}
\hline \multicolumn{5}{|l|}{ Tank Waste Information Network System (TWINS) } \\
\hline \multirow{2}{*}{$\begin{array}{l}\text { Waste } \\
\text { Tank }\end{array}$} & \multicolumn{3}{|c|}{ SACS Tank Temperature(1) } \\
\cline { 2 - 5 } & $\begin{array}{r}\text { Maximum } \\
\left({ }^{\circ} \text { F) }\right.\end{array}$ & $\begin{array}{r}\text { Minimum } \\
\left({ }^{\circ} \text { F) }\right.\end{array}$ & \multicolumn{1}{r|}{$\begin{array}{c}\text { Thermocouple } \\
\text { Number: }\end{array}$} \\
\hline AN-101 & 77.4 & 53.2 & 2 & 1 \\
\hline AN-102 & 91 & 70.5 & 16 & 1 \\
\hline AN-103 & 106.9 & 65.8 & 8 & 1 \\
\hline AN-104 & 107.2 & 66.7 & 7 & 1 \\
\hline AN-105 & 102.4 & 68.7 & 5 & 1 \\
\hline AN-107 & 107.6 & 6537 & 1 & 1 \\
\hline AP-101 & 70.8 & 59 & 12 & 18 \\
\hline AP-104 & 19.7 & 54.2 & 8 & 18 \\
\hline AP-105 & 71.1 & 60.1 & 18 & 18 \\
\hline AP-106 & 82.4 & 56.3 & 12 & 17 \\
\hline AP-108 & 72 & 55.4 & 14 & 12 \\
\hline AW-101 & 99.8 & 66.5 & 4 & 1 \\
\hline AW-103 & 71.7 & 60.9 & 1 & 1 \\
\hline AW-104 & 80.7 & 59.7 & 2 & 1 \\
\hline AY-101 & 119.37 & 74.7 & 1 & 1 \\
\hline AY-102 & 140 & 69.6 & 1 & 1 \\
\hline AZ-101 & 179.6 & 117.5 & 1 & 1 \\
\hline AZ-102 & 163.9 & 89.2 & 1 & 1 \\
\hline C-104 & 96.6 & 81 & 1 & 8 \\
\hline C-106 & 147.9 & 43.7 & 1 & 3 \\
\hline C-107 & 119.3 & 101 & 3 & 6 \\
\hline S-102 & 102.9 & 76.1 & 3 & 6 \\
\hline S-103 & 88 & 69.4 & 1 & 6 \\
\hline S-105 & 77.7 & 63.1 & 1 & 12 \\
\hline S-106 & 77.9 & 61.7 & 4 & 12 \\
\hline S-108 & 82.4 & 63 & 3 & 10 \\
\hline SY-101 & 126.3 & 61.2 & 15 & 18 \\
\hline SY-102 & 109.6 & 62 & 14 & 1 \\
\hline SY-103 & 95.2 & 73 & 4 & 1 \\
\hline
\end{tabular}

Notes: (1) Maximum and minimum temperature over a 12 month time period (7/18/99 to 7/18/00). Bold type shows the highest temperatures for LAW and HLW. 
RPP-6735, REV. 0

\section{APPENDIX C}

Maximum Designed Waste Depth in

Phase 1 Case 3S6 LAW and HLW DST Feed Tanks

C-1 
Maximum Designed Waste Depth in

Phase 1 Case 3S6 LAW and HLW DST Feed Tanks

The Phase 1, Case 3S6 waste tanks vary in dimensions and in the amount of waste each tank can hold. Table C-1 shows the design waste depth for each of the waste tanks. The sampling system must be capable of obtaining representative samples at any specific waste elevation over this waste depth span, within \pm 1.0 -inches.

Table C-1 Maximum depth of waste that each of the Phase 1 Case 3S6 waste tanks can hold.

\begin{tabular}{|c|c|c|}
\hline \multirow{2}{*}{ Waste Tank } & \multicolumn{2}{|c|}{$\begin{array}{c}\text { Maximum Waste } \\
\text { Depth }\end{array}$} \\
\cline { 2 - 3 } & (inches) & (feet) \\
\hline AP-101 & 422 & 35.17 \\
\hline$A P-102$ & 422 & 35.17 \\
\hline$A P-104$ & 422 & 35.17 \\
\hline$A N-101$ & 422 & 35.17 \\
\hline$A N-102$ & 422 & 35.17 \\
\hline$A N-103$ & 422 & 35.17 \\
\hline$A N-104$ & 422 & 35.17 \\
\hline$A N-105$ & 422 & 35.17 \\
\hline$A N-107$ & 422 & 35.17 \\
\hline$A W-101$ & 422 & 35.17 \\
\hline SY-101 & 422 & 35.17 \\
\hline SY-102 & 422 & 35.17 \\
\hline$A Y-101$ & 377 & 30.83 \\
\hline$A Y-102$ & 377 & 30.83 \\
\hline$A Z-101$ & 377 & 30.83 \\
\hline$A Z-102$ & 377 & 30.83 \\
\hline
\end{tabular}

